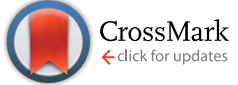

Cite this: RSC Adv., 2015, 5, 78047

Received 12th August 2015

Accepted 8th September 2015

DOI: 10.1039/c5ra16213k

www.rsc.org/advances

\section{On the investigation of hybrid quinones: synthesis, electrochemical studies and evaluation of trypanocidal activity $\dagger$}

\author{
Guilherme A. M. Jardim, ${ }^{a}$ Wallace J. Reis, ${ }^{a}$ Matheus F. Ribeiro, ${ }^{a}$ Flaviano M. Ottoni, ${ }^{b}$ \\ Ricardo J. Alves, ${ }^{b}$ Thaissa L. Silva, ${ }^{c}$ Marilia O. F. Goulart, ${ }^{c}$ Antonio L. Braga, ${ }^{d}$ \\ Rubem F. S. Menna-Barreto, ${ }^{e}$ Kelly Salomão, ${ }^{e}$ Solange L. de Castro ${ }^{e}$ \\ and Eufrânio N. da Silva Júnior*a
}

In our continued search for novel trypanocidal compounds, arylamine, chalcone, triazolic, triazolecarbohydrate and chalcogenium derivatives containing a naphthoquinone scaffold were prepared; in addition to electrochemical studies, these compounds were evaluated against the infective bloodstream form of Trypanosoma cruzi, the etiological agent of Chagas disease. Among the thirty-eight compounds herein evaluated, six were found to be more potent against trypomastigotes than the standard drug benznidazole, with $\mathrm{IC}_{50} / 24 \mathrm{~h}$ values between 52.9 and $89.5 \mu \mathrm{M}$.

\section{Introduction}

Chagas disease is caused by the protozoan Trypanosoma cruzi ( $T$. cruzi) and affects approximately 5.7 million individuals in Latin America, of whom $30-40 \%$ either have or will develop cardiomyopathy, digestive megasyndromes or both. ${ }^{1}$ The transmission of Chagas disease occurs through the faeces of sucking triatominae insects, blood transfusions, organ transplantation, oral contamination through laboratory accidents and congenital routes. ${ }^{2}$ A current major concern is related to outbreaks of acute Chagas disease associated with the ingestion of contaminated food and drink. ${ }^{3,4}$ Another concern is the disease's emergence in non-endemic areas such as North America and Europe, a phenomenon that is likely due to the immigration of infected individuals. ${ }^{5,6}$ This disease is characterised by two clinical phases: a short, acute phase defined by patent parasitaemia and a long, progressive chronic phase. ${ }^{7}$

The life cycle of $T$. cruzi involves obligatory passage through vertebrate and invertebrate hosts in a series of different developmental stages. ${ }^{8}$ The trypomastigote is ingested by the insect and differentiates into epimastigote form, which differentiates into the metacyclic trypomastigote form. Following the invasion of vertebrate host cells, this form differentiates into the

${ }^{a}$ Institute of Exact Sciences, Department of Chemistry, UFMG, Belo Horizonte, MG, 31270-901, Brazil. E-mail: eufranio@ufmg.br

${ }^{b}$ School of Pharmacy, UFMG, Belo Horizonte, MG, 31270-901, Brazil 'Institute of Chemistry and Biotechnology, UFAL, Maceió, AL, 57072-970, Brazil

${ }^{d}$ Department of Chemistry, UFSC, Florianópolis, SC, 88040-900, Brazil

${ }^{e}$ Laboratory of Cellular Biology, IOC, FIOCRUZ, Rio de Janeiro, RJ, 21045-900, Brazil

$\dagger$ Electronic supplementary information (ESI) available. See DOI: $10.1039 / \mathrm{c} 5 \mathrm{ra16213k}$ amastigote, which after several reproductive cycles, transforms into the trypomastigote form, which is responsible for dissemination of the infection.

The available chemotherapy for this illness includes two nitroheterocyclic agents, nifurtimox and benznidazole (Bnz). These two agents are effective against acute infections but show poor activity, severe collateral effects and limited efficacy against different parasitic isolates in the late chronic phase. Thus, there is an urgent need to identify better drugs to treat chagasic patients. ${ }^{\mathbf{9}, 10}$

Among several naturally occurring compounds, the naphthoquinones have emerged with a broad distribution in the plant kingdom; naphthoquinones are involved in oxidative processes due to their structural properties and their capacity to generate reactive oxygen species. ${ }^{\mathbf{1 1}, \mathbf{1 2}}$ Quinoidal compounds can be found in various plant families or as synthetic substances ${ }^{\mathbf{1 3 , 1 4}}$ and are the focus of research aimed at the identification of derivatives with efficacy and selectivity toward T. cruzi. ${ }^{15}$

Lapachol (1) is an important natural naphthoquinone; our group has focused on synthesising and evaluating the trypanocidal activity of lapachones substituted with 1,2,3-triazole moieties. ${ }^{15}$ The broad and potent activity of triazole and their derivatives has established them as pharmacologically significant scaffolds. ${ }^{\mathbf{1 6 , 1 7}}$ The catalysis by $\mathrm{Cu}(\mathrm{I})$ of 1,3-dipolar cycloadditions between azides and terminal alkynes ${ }^{\mathbf{1 8}}$ led to enhanced reactivity and regioselectivity, resulting in the formation of 1,4disubstituted 1,2,3-triazoles. ${ }^{19}$ This conversion has been used increasingly in drug discovery due to its reliability, specificity, and biocompatibility; also, triazoles can act as both a bioisostere and a linker that readily associates with biological targets through hydrogen-bonding and dipole interactions. ${ }^{20}$ 
Over the years, our group has investigated the synthesis, selectivity, and mechanisms of action of quinoidal compounds in relation to T. cruzi. ${ }^{21}$ The synthetic strategies involved A-ring, C-ring and redox centre modifications of lapachones. ${ }^{15,21,22}$ For instance, naphthoimidazoles were prepared by redox centre modification of $\beta$-lapachone; among the derivatives assayed, three compounds were active against bloodstream trypomastigotes of T. cruzi (Scheme 1a). ${ }^{\mathbf{2 3 , 2 4}}$ 3-Arylamino nor- $\beta$-lapachones represent an important example of C-ring-modified lapachones. The compounds were effective against trypomastigote forms, with nor- $\beta$-lapachone dibromo-substituted arylamine exhibiting approximately four times more activity than $\mathrm{Bnz}$, the standard drug (Scheme 1a). ${ }^{25}$ Nor- $\beta$-lapachone-based 1,2,3-triazole (which is two times more active than Bnz) was also effective against the proliferative forms of T. cruzi (Scheme 1a). ${ }^{26,27}$ Silva and co-workers ${ }^{28}$ described the synthesis of iodinated and methylated naphthoquinones obtained from C-allyl lawsone (Scheme 1a) that were active against epimastigotes and trypomastigotes of $T$. cruzi, with the main target being the mitochondrion. ${ }^{29}$

a) Trypanocidal compounds obtained by redox centre or C-ring modifications

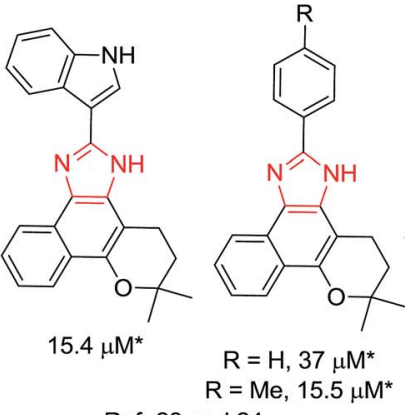

Ref. 23 and 24

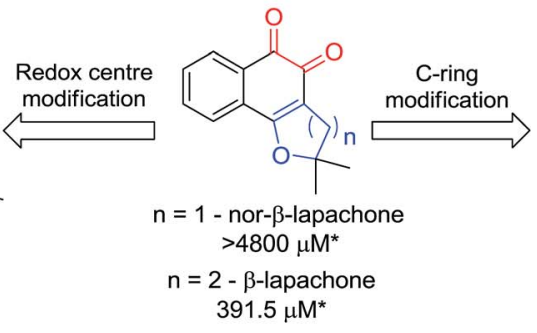

$391.5 \mu \mathrm{M}^{*}$

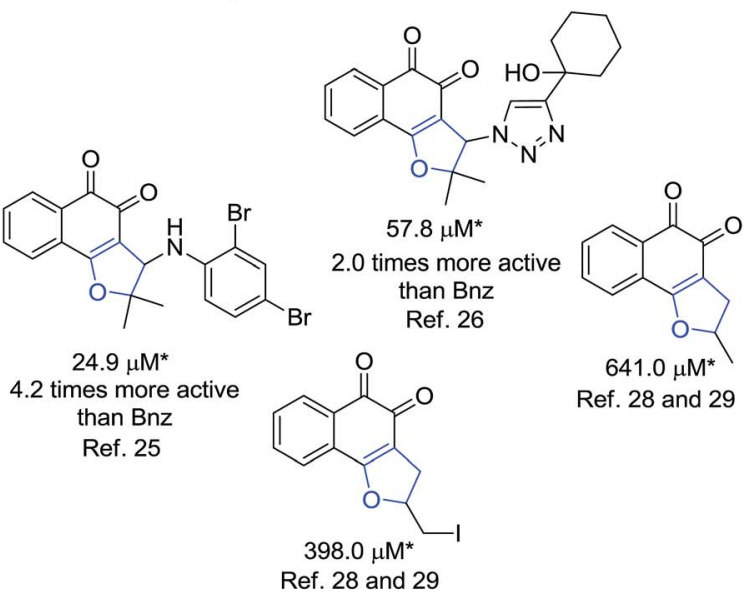

Ref. 28 and 29

\section{b) Examples of carbohydrate and chalcone hybrids with trypanocidal activity}<smiles>OCC1O[C@@H](n2cc(Cc3ccccc3)nn2)C(O)[C@@H](O)[C@@H]1O</smiles>

Ref. 31

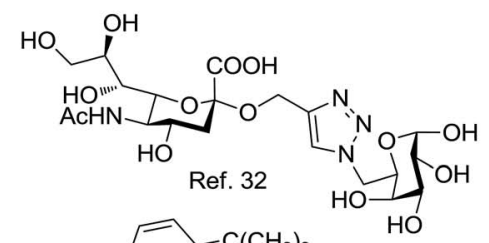<smiles>C=CC(=O)c1c(O)c2ccccc2[nH]c1=O</smiles>

Ref. 35<smiles>COc1cc(C(=O)/C=C/c2ccc3c(c2)B(O)OC3)ccc1N</smiles>

Ref. 36

Ref. 37

c) Quinones evaluated in this work against T. cruzi.<smiles>[R]c1ccc(NC2CC(C)(C)OC3=C2C(=O)c2ccccc2C3=O)cc1</smiles><smiles>[R]CNC1C2=C(OC1(C)C)c1ccccc1C(=O)C2=O</smiles><smiles>[R]c1ccc(/C=C/C(=O)c2ccc(N)cc2)cc1</smiles><smiles>[R]c1cn(CC2CC3=C(O2)c2ccccc2C(=O)C3=O)nn1</smiles><smiles>CCc1cn(CC2CC3=C(O2)c2ccccc2C(=O)C3=O)nn1</smiles>

$\mathrm{R}=$ Electron donating and withdrawing groups

\section{Carbohydrate} derivatives<smiles>CCc1cn(C2C(=O)c3ccccc3C3=C2CC(C)(C)O3)nn1</smiles>

\section{Carbohydrate} derivatives<smiles>[R]CC1(C)OC2=C(CC1[X])C(=O)C(=O)c1ccccc12</smiles> 
The triazole moiety is also used for the synthesis of glycosylated structures..$^{30}$ For example, a series of sugar triazoles has been synthesized, and 1,2,3-triazole-linked sialic acid-6-Ogalactose was active in vitro against $T$. cruzi. ${ }^{31}$ Recently, Campo and co-workers described 1,4-disubstituted 1,2,3-triazole-sialic acid derivatives containing galactose, glucose or gulose as potential inhibitors of $T$. cruzi trans-sialidase (Scheme 1b). ${ }^{32}$

Chalcones can be readily synthesized by the ClaisenSchmidt condensation method, ${ }^{33}$ and they represent a key moiety in medicinal chemistry, displaying a wide range of pharmacological activities. ${ }^{34}$ Hybrids of chalcone with quinolinone ${ }^{35}$ paullone ${ }^{36}$ and benzoxaborole ${ }^{37}$ have shown significant activity against pathogenic trypanosomatids and low cytotoxicity to mammalian cells (Scheme $1 b$ ).

Finally, several reports have described chalcogen-containing quinones with antibacterial, antifungal ${ }^{38}$ and antitumor activities, ${ }^{39}$ and the last two decades have witnessed a growing interest in selenium-containing compounds with potential 'redox modulating' properties. Certain redox catalysts containing quinone- and chalcogen-bearing building blocks have shown considerable importance, with activity against cancer cells and other biological targets. ${ }^{40}$

In this context, we herein describe the synthesis and trypanocidal activity of (i) $\alpha$-lapachone arylamines: as discussed above, the presence of an arylamino group in nor- $\beta$-lapachone improves the trypanocidal activity, and the biological activity of 4-arylamino $\alpha$-lapachone remains unexplored; (ii) nor- $\beta$-lapachonebased chalcones: we aim to obtain active compounds, due to the well-known bioactivity of each individual moiety; (iii) quinone-based 1,2,3-triazoles from C-allyl lawsone: the insertion of 1,2,3-triazole could enhance the trypanocidal activity of the derivatives previously shown to be less active than Bnz, as displayed in Scheme 1a; ${ }^{15}$ (iv) naphthoquinone-based 1,2,3-triazole linked to monosaccharides: sugar residues are able to modulate physicochemical parameters, such as solubility and interactions with cell surface components, which are both important parameters enabling a drug to act on intracellular parasites; and (v) selenium- and sulphur-containing lapachones: for the first time, this class of compounds is evaluated against $T$. cruzi and subjected to concise electrochemical studies (Scheme 1c).

\section{Results and discussion}

\section{Chemistry}

To obtain $\alpha$-lapachone arylamines, $\alpha$-lapachone (2) was prepared in an initial step from lapachol (1) in acidic conditions. ${ }^{41}$ Then, 2 was reacted with NBS in $\mathrm{CCl}_{4}$ using benzoyl peroxide as an initiator to afford 4-bromo- $\alpha$-lapachone; a nucleophilic substitution reaction with substituted anilines gave the compounds 3-14 (Scheme 2). We recently reported compounds 3-7, 9-10 and 14, ${ }^{42}$ and compounds 8, 11-13 are herein described for the first time. In order to achieve nor- $\beta$-lapachone-based chalcones, aminochalcones were synthesized via a Claisen condensation reaction with $4^{\prime}$-aminoacetophenone and different aldehydes in the presence of sodium hydroxide in ethanol. ${ }^{43}$ Then, nor-lapachol $(\mathbf{1 5})^{44}$ was treated with excess bromine to obtain 3-bromo-nor- $\beta$-lapachone (16) in quantitative yield..$^{41}$ Through a nucleophilic substitution reaction with amino-chalcones and 16, compounds 17-21 were prepared as previously published (Scheme 2$)^{45}$

To obtain the third class of substances, C-allyl-lawsone (22) was prepared in an initial step from the reaction of lawsone with allyl bromide. ${ }^{46}$ In a second step, 22 was treated with excess iodine,$^{28}$ forming the para and ortho regioisomers. The iodinated naphthoquinone $\mathbf{2 3}$ (ortho-derivative) was obtained in moderate yield as a crystalline red solid after separation by column chromatography. Compound $\mathbf{2 4}$ was synthesized in

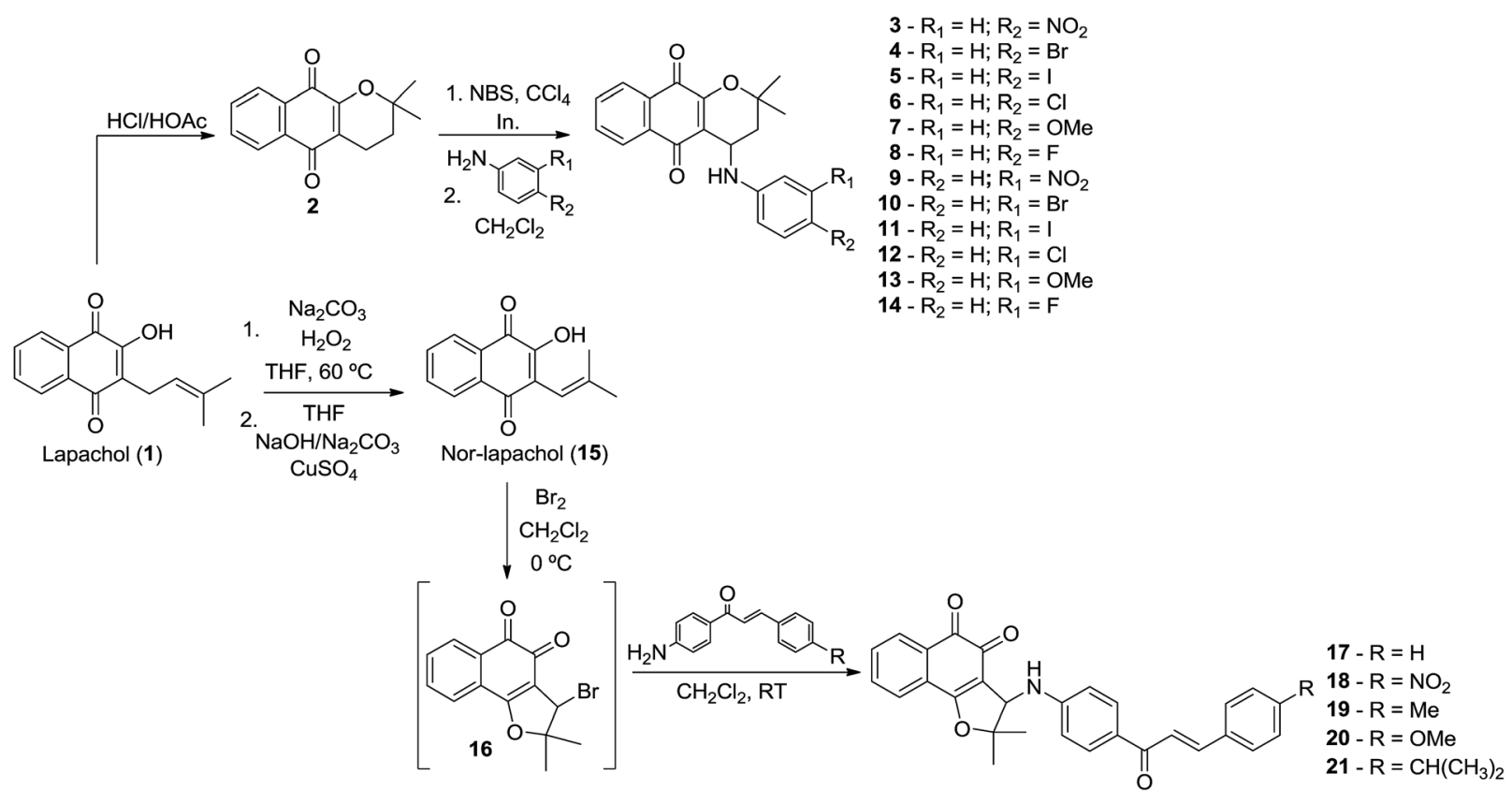

Scheme 2 Synthesis of $\alpha$-lapachone arylamines and nor- $\beta$-lapachone-based chalcones. 


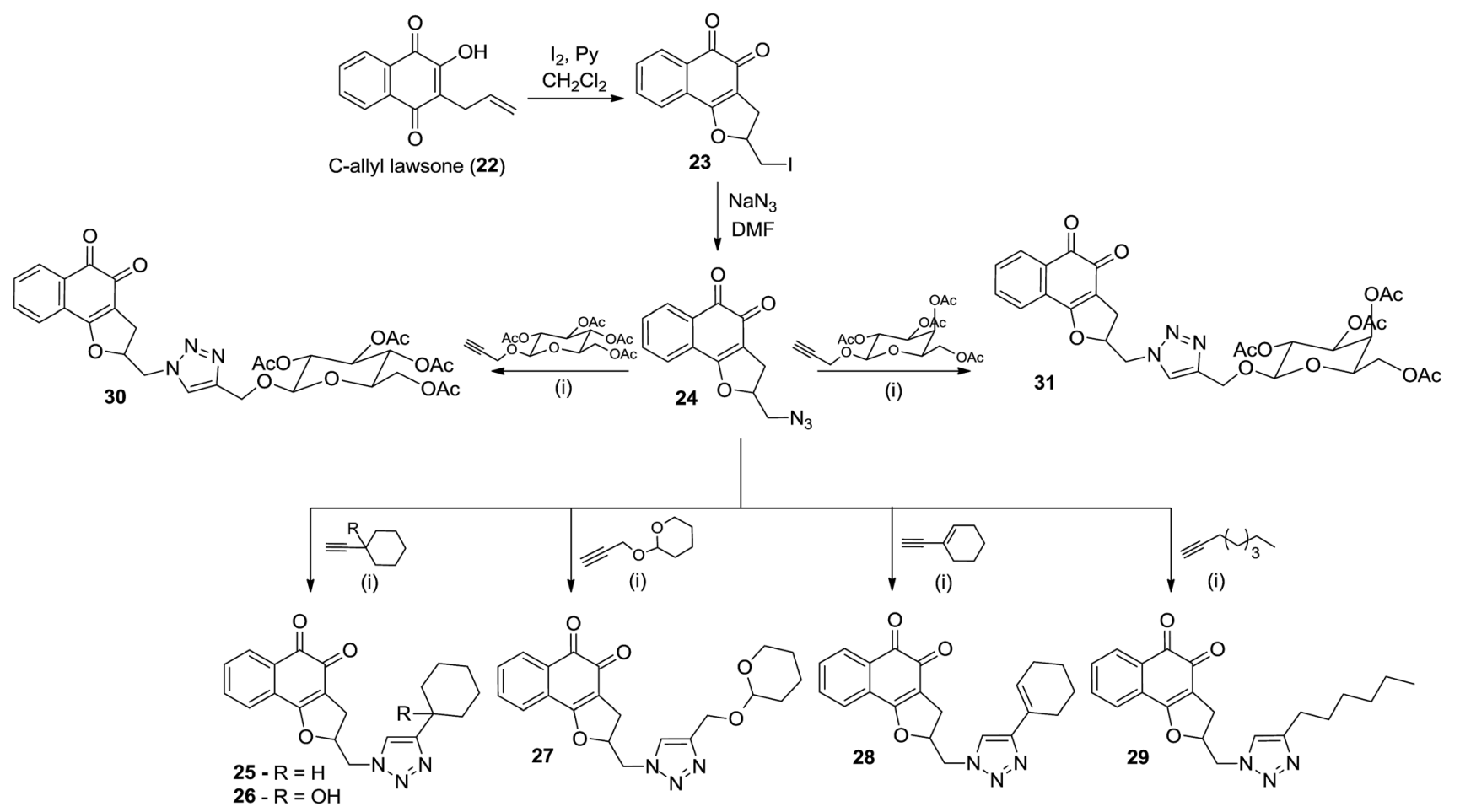

Scheme 3 Synthesis of quinone-based 1,2,3-triazoles 26-30 and linkage to monosaccharides to give 30 and 31 . Conditions (i): $\mathrm{CuSO}_{4} \cdot 5 \mathrm{H}_{2} \mathrm{O}$, sodium ascorbate, $\mathrm{CH}_{2} \mathrm{Cl}_{2} / \mathrm{H}_{2} \mathrm{O}$.

good yield via nucleophilic substitution of $\mathbf{2 3}$ with sodium azide in dimethylformamide (DMF), as previously described. ${ }^{47}$ The 1,2,3-triazole derivatives were obtained through a click reaction of 24 with $\mathrm{CuSO}_{4} \cdot 5 \mathrm{H}_{2} \mathrm{O}$ /sodium ascorbate and the corresponding alkynes in a mixture of $\mathrm{CH}_{2} \mathrm{Cl}_{2} / \mathrm{H}_{2} \mathrm{O}$, giving 25-29. Alkyne derivatives of monosaccharides were also used in the

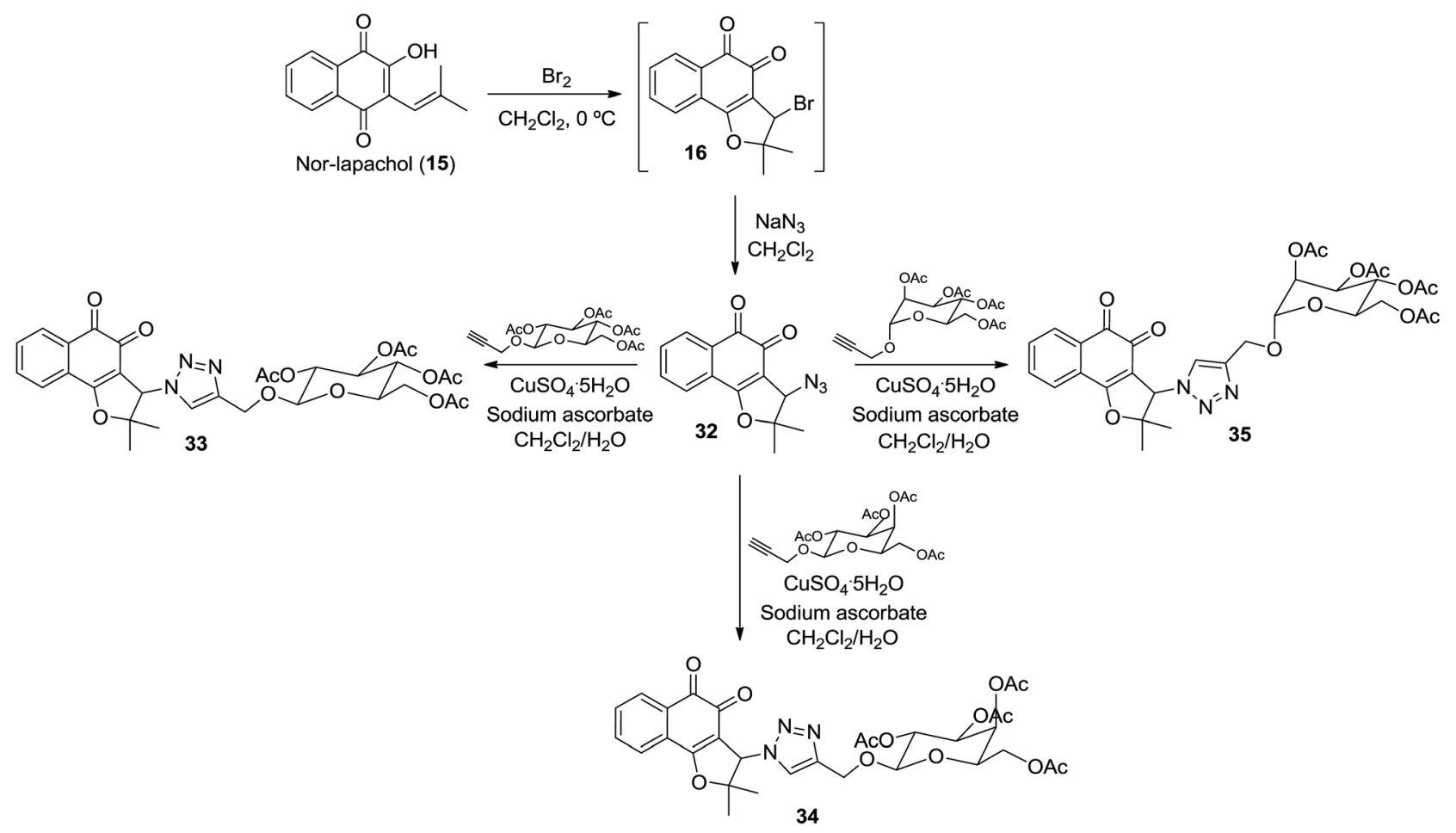

Scheme 4 Synthesis of nor- $\beta$-lapachone-based 1,2,3-triazole-carbohydrates 33-35. 
click reaction, providing 30-31 (Scheme 3). These alkynecarbohydrate derivatives were obtained using two different methods of acetylation. ${ }^{\mathbf{4 8 , 4 9}}$ For the glucose and galactose derivatives, D-glucose and D-galactose were subjected to peracetylation with $\mathrm{NaOAc}$ in acetic anhydride, and the compounds were prepared in moderate yields. For the mannose derivative, catalytic amounts of $\mathrm{I}_{2}$ were used instead of NaOAc. The product was reacted with propargyl alcohol and catalytic amounts of $\mathrm{BF}_{3} \cdot \mathrm{Et}_{2} \mathrm{O}$ in $\mathrm{CH}_{2} \mathrm{Cl}_{2}$ to achieve the alkyne derivative. ${ }^{50}$

To prepare nor- $\beta$-lapachone-based monosaccharide-linked 1,2,3-triazoles, bromo derivative 16 was subjected to a nucleophilic substitution reaction with sodium azide in dichloromethane to obtain 32 in quantitative yield, as previously reported. ${ }^{26}$ From the reaction of 32 with $\mathrm{CuSO}_{4} \cdot 5 \mathrm{H}_{2} \mathrm{O}$ /sodium ascorbate and the alkyne derivatives of glucose, mannose and galactose in a mixture of $\mathrm{CH}_{2} \mathrm{Cl}_{2} / \mathrm{H}_{2} \mathrm{O}$, compounds 33-35 were obtained in good yields (Scheme 4 ).

Finally, as recently described, ${ }^{51}$ the chalcogenylation of lapachol (1) was induced under microwave irradiation and using molecular iodine as a catalyst, DMSO as a stoichiometric oxidant and different chalcogenium compounds, affording the selenium- and sulphur-containing $\beta$-lapachone derivatives (Scheme 5).

The structures of the novel compounds 8, 11-13, 25-31 and 33-35 were determined by ${ }^{1} \mathrm{H}$ and ${ }^{13} \mathrm{C}$ NMR. Electrospray ionization mass spectra were also obtained. The ${ }^{1} \mathrm{H}$ and ${ }^{13} \mathrm{C}$ NMR spectra for all unpublished compounds are included in the ESI. $\dagger$

\section{Biological and electrochemical analysis}

The compounds 3-14, 17-21, 25-31 and 33-46 were evaluated against trypomastigote forms of $T$. cruzi. The more active compounds against $T$. cruzi were 14, 26-29 and 41, which exhibited $\mathrm{IC}_{50} / 24 \mathrm{~h}$ values in the range of 52.9 to $89.5 \mu \mathrm{M}$, in comparison with the $\mathrm{IC}_{50} / 24 \mathrm{~h}$ value of $103.6 \mu \mathrm{M}$ for the reference drug, Bnz. Thus, in general, these compounds are approximately two times more potent than Bnz (Table 1).

Table 1 Activity of compounds against the trypomastigote form of T. cruzi

\begin{tabular}{|c|c|c|c|}
\hline Compd & $\mathrm{IC}_{50} / 24 \mathrm{~h}^{a}(\mu \mathrm{M})$ & Compd & $\mathrm{IC}_{50} / 24 \mathrm{~h}^{a}(\mu \mathrm{M})$ \\
\hline 1 & $410.8 \pm 53.2^{b}$ & 26 & $89.5 \pm 2.8$ \\
\hline 2 & $>4000^{b}$ & 27 & $52.9 \pm 2.1$ \\
\hline 3 & $>4000$ & 28 & $55.3 \pm 5.2$ \\
\hline 4 & $911.0 \pm 42.2$ & 29 & $86.7 \pm 5.4$ \\
\hline 5 & $374.5 \pm 179.5$ & 30 & $300.3 \pm 21.1$ \\
\hline 6 & $>4000$ & 31 & $174.9 \pm 10.6$ \\
\hline 7 & $>4000$ & 32 & $50.2 \pm 3.8^{d}$ \\
\hline 8 & $1471.3 \pm 171.6$ & 33 & $472.2 \pm 16.5$ \\
\hline 9 & $>4000$ & 34 & $208.9 \pm 7.3$ \\
\hline 10 & $1093.8 \pm 133.1$ & 35 & $202.3 \pm 6.0$ \\
\hline 11 & $>4000$ & 36 & $102.9 \pm 0.0$ \\
\hline 12 & $440.6 \pm 73.0$ & 37 & $1677.8 \pm 113.3$ \\
\hline 13 & $>4000$ & 38 & $207.6 \pm 33.52$ \\
\hline 14 & $89.3 \pm 6.0$ & 39 & $360.5 \pm 34.6$ \\
\hline 15 & $1280.6 \pm 167.2^{b}$ & 40 & $477.1 \pm 14.83$ \\
\hline 17 & $>4000$ & 41 & $54.9 \pm 3.19$ \\
\hline 18 & $>4000$ & 42 & $251.9 \pm 52.51$ \\
\hline 19 & $787.4 \pm 40.6$ & 43 & $>4000$ \\
\hline 20 & $230.2 \pm 71.6$ & 44 & $281.8 \pm 3.45$ \\
\hline 21 & $>4000$ & 45 & $109.2 \pm 33.2$ \\
\hline 22 & $352.0 \pm 29.0^{c}$ & 46 & $>4000$ \\
\hline 23 & $398.0 \pm 56.0^{c}$ & Benznidazole $^{d}$ & $103.6 \pm 0.6$ \\
\hline 25 & $213.5 \pm 8.4$ & Crystal violet $^{b}$ & $536.0 \pm 3.0$ \\
\hline
\end{tabular}

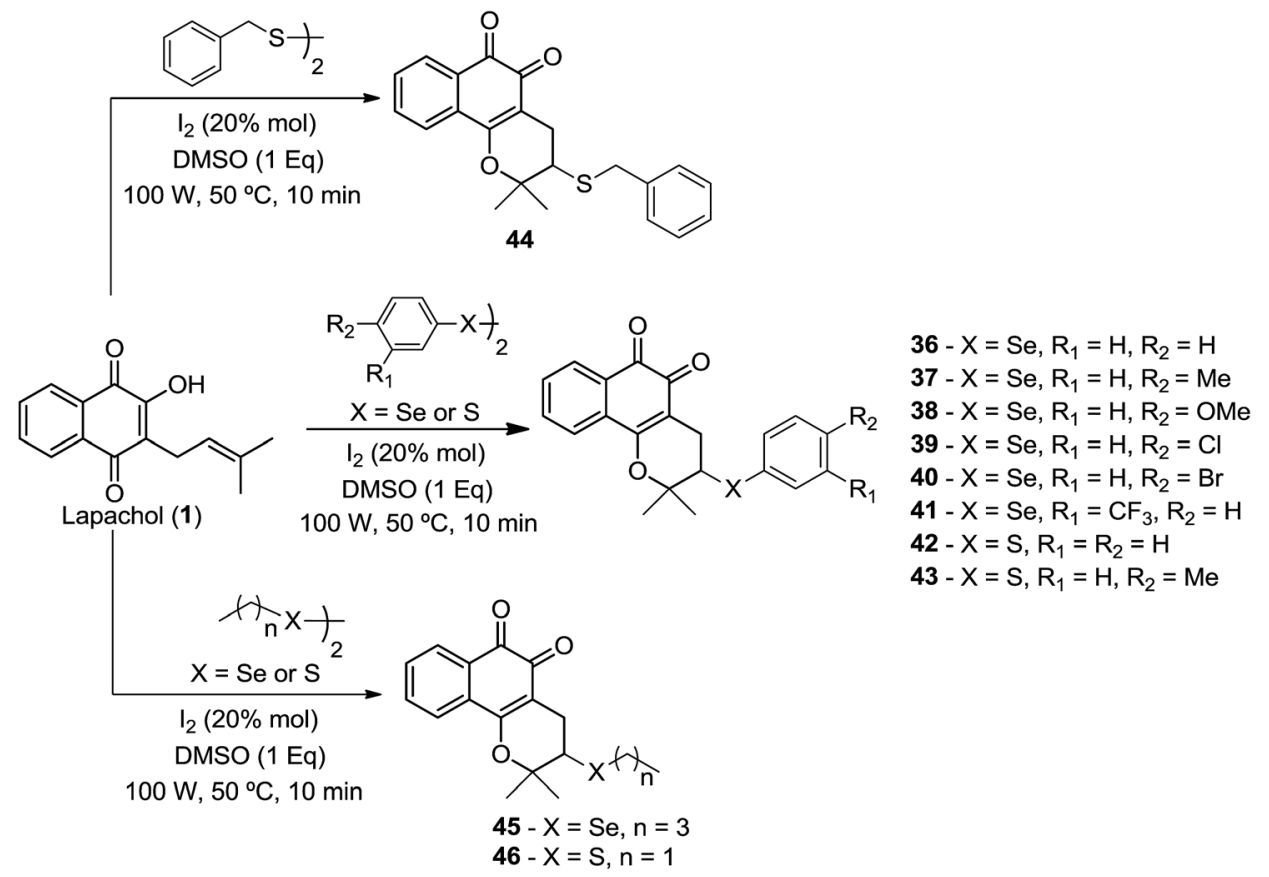

Scheme 5 Chalcogenium-containing $\beta$-lapachone derivatives 36-46 evaluated against $T$. cruzi. 
We recently described the arylamino-substituted $\alpha$-lapachone compounds $\mathbf{3 - 1 4}$ as having moderate antitumor activity. ${ }^{42}$ Herein, we prepared a series of arylamino-substituted $\alpha$-lapachone compounds possessing electron-withdrawing and electron-donating groups. No clear structure-activity relationship was observed, and all the compounds were either inactive or presented low activity, with the exception of compound $\mathbf{1 4}$ $\left(\mathrm{IC}_{50} / 24 \mathrm{~h}\right.$ of $\left.89.3 \mu \mathrm{M}\right)$.

As discussed before, chalcones represent an important class of compounds with trypanocidal activity. ${ }^{33-37}$ Based on this previously determined biological activity, we prepared and evaluated the nor- $\beta$-lapachone-based chalcone hybrids 17-21. These compounds were previously shown to possess potent antitumor activity. ${ }^{45}$ Unfortunately, the compounds failed to kill T. cruzi, and the derivatives were considered inactive; the exception was compound $20\left(\mathrm{IC}_{50} / 24 \mathrm{~h}\right.$ of $\left.230.2 \mu \mathrm{M}\right)$, which presented moderate activity against trypomastigote forms of the parasite.

The third class of compounds, lapachone derivatives obtained from C-allyl lawsone (22), are promising trypanocidal agents. We recently used molecular hybridization of naphthoquinoidal compounds and 1,2,3-triazoles to design trypanocidal derivatives. ${ }^{25,26,52}$ We discovered, for instance, four classes of naphthoquinone-based 1,2,3-triazoles, which are exemplified by compounds 47-52 (Fig. 1), which have the pronounced ability to inhibit the infective bloodstream form of T. cruzi and are more active than Bnz. We described some insights about the mechanism of action of 48. This substance induced reservosome disruption, flagellar blebbing and Golgi disorganization in the parasites. According to our studies, autophagy could be a part of the mechanism of action for this derivative. ${ }^{53}$

In our search for novel quinone-based 1,2,3-triazoles, we herein describe for the first time a series of triazolic derivatives prepared from C-allyl lawsone (22) (Scheme 3). Compounds 26, 27, 28 and 29, with $\mathrm{IC}_{50} / 24 \mathrm{~h}$ values of 89.5, 52.9, 55.3 and 86.7 $\mu \mathrm{M}$, respectively, presented important trypanocidal activity and

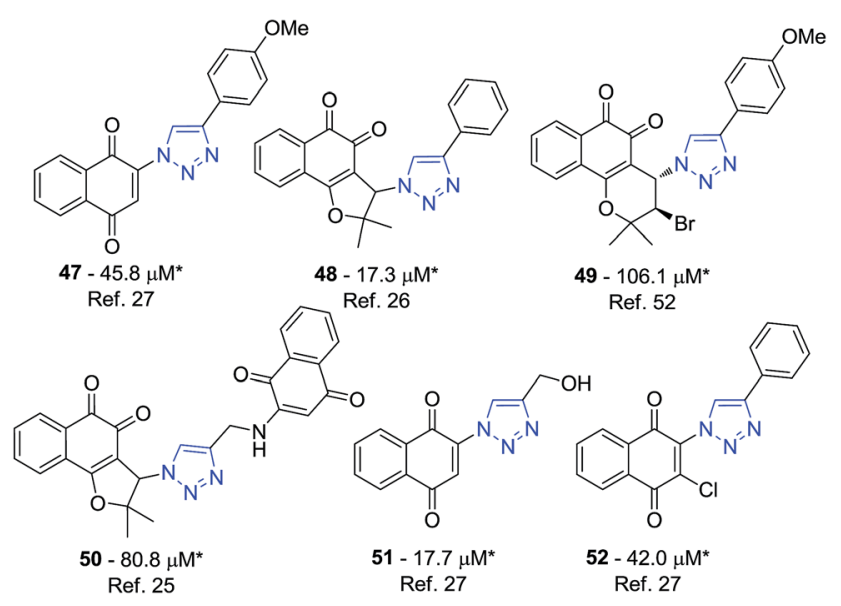

Fig. 1 Trypanocidal compounds designed by molecular hybridization of quinones and 1,2,3-triazoles. * $\mathrm{IC}_{50} / 24 \mathrm{~h}$ values for the lytic activity on bloodstream trypomastigotes. will be considered for further studies. These derivatives were obtained in only three steps from C-allyl lawsone (22), and 27 and $\mathbf{2 8}$ were almost twice as active as Bnz. Additionally, we prepared lapachone coupled with carbohydrate derivatives $\mathbf{3 0}$, 31 and 33-35 to evaluate the ability of these compounds to generate damage to the parasite. We observed that these new compounds presented moderate activity against $T$. cruzi, but the compounds were less active than Bnz. In general terms, the strategy was efficient, but further structural modifications will be required to improve the biological potential of these compounds.

We recently described the last class of compounds as possessing potential antitumor activity. ${ }^{51}$ Selenium- and sulphurcontaining $\beta$-lapachone derivatives 33-46 were active against T. cruzi with generally moderate activity; however, compounds $41\left(\mathrm{IC}_{50} / 24 \mathrm{~h}=54.9 \mu \mathrm{M}\right), 36\left(\mathrm{IC}_{50} / 24 \mathrm{~h}=102.9 \mu \mathrm{M}\right)$ and $45\left(\mathrm{IC}_{50} /\right.$ $24 \mathrm{~h}=109.2 \mu \mathrm{M})$ exhibited $\mathrm{IC}_{50}$ values similar to that of $\mathrm{Bnz}$, and 41 was 2 -fold more potent than Bnz. Herein, we describe detailed studies of the electrochemical aspects of these compounds, as only a few examples of chalcogeniumcontaining lapachones have been reported, along with evaluation of anticancer activity. To the best of our knowledge, this is the first joint report of electrochemistry and trypanocidal activity results, related to this class of compounds.

In addition, we also evaluated the cytotoxicity of the most active compounds against peritoneal macrophages. The results showed that the active substances were more toxic to the parasites than to the cell lines tested. Finally, our results demonstrated that compounds 14 and 26-29 are the most active against this trypanosomatid and may represent promising compounds for treatment of Chagas disease.

Molecular electrochemistry, through non-destructive techniques such as cyclic voltammetry in aprotic and protic media, has proved to be very useful for characterizing electron transfers and deciphering chemical reaction mechanisms that are associated with electron transfer, with some correlation with redoxbased biological activity. ${ }^{12,54}$ In this context, our group has described the synthesis and electrochemical studies of several quinones in an attempt to correlate them with trypanocidal activity, ${ }^{55}$ as well as the electrochemical aspects of arylaminosubstituted $\alpha$-lapachones and nor- $\beta$-lapachones. ${ }^{42,52,56}$

Among all the investigated multifunctional compounds herein described, only a few examples of electrochemical studies on chalcogen-containing quinones have been reported in the literature. ${ }^{40}$ In order to corroborate the biological aspects of selenium- and sulphur-containing $\beta$-lapachones and establish more insight using electrochemical parameters, we performed experiments with the compounds 36-39, 40, 41 and 45. Using cyclic voltammetric studies in aprotic $\left(\mathrm{DMF}^{\mathrm{T}} \mathrm{TBAPF}_{6}\right)$ and protic (ethanolic phosphate buffered medium at $\mathrm{pH}$ 7.4) media, the two redox centres (quinoidal and organochalcogen moieties) were investigated. ${ }^{57}$ The electrochemical properties of organic selenium compounds ${ }^{58,59}$ qualitatively resemble those of the more abundant sulphur compounds, although they are much less explored. The number of redox potentials of organoselenium organic compounds is limited. The products of electrochemical oxidation are remarkably dependent upon the 
structure of the organic moiety, the water content of the solvent, and the supporting electrolyte. ${ }^{58}$

In the present case, cyclic voltammogram (CV) was used to investigate the electrochemical behaviour of the seven selenoquinones $36-39,40,41$, and 45 , which were recently reported as antitumor compounds. ${ }^{51}$ The obtained profiles confirmed the presence of two individual redox centres.

In typical measurements, CVs were recorded in aprotic medium (DMF $+\mathrm{TBAPF}_{6}, 0.1 \mathrm{~mol} \mathrm{~L}^{-1}$ ) to resemble the membrane environment at a scan rate of $100 \mathrm{mV} \mathrm{s}^{-1}$. This enabled the determination of the electrochemical reduction (from 0.5 up to $-3.0 \mathrm{~V}$ ) and oxidation (from -0.5 up to $2.0 \mathrm{~V}$ ) behaviours of each compound. Cathodic and anodic peak potentials for each compound are listed in Table 2. All the compounds showed electrochemical activity in the cathodic and anodic arms of the CVs, as represented by compound 38 (Fig. 2).

The voltammograms for compounds 36-39, 40, 41 and 45 displayed similar profiles in the cathodic and anodic regions. Fig. 3 shows the electrochemical behaviour of compound $\mathbf{4 0}$ as a representative of the series.

As expected, the overall CV profiles for the quinonoid compounds are similar to those reported for other quinones. ${ }^{42,53,60}$ One couple of cathodic and anodic peaks is represented by a diffusional $\left(E_{\mathrm{pIc}} \propto \nu^{1 / 2}\right)$ quasi-reversible nature (Ic/Ia). This first pair is related to the anion-radical (semiquinone) formation, and the second pair of peaks is broader and ill-defined (IIc/IIa), as observed before, ${ }^{60}$ due to a possible disproportionation of ortho-quinones (Fig. 3a and b). In the anodic region, a sharp, irreversible peak (IVa) appears, with at least a duplicated current intensity. In the reversed cycle, a reduction wave (IVc) is observed close to $0 \mathrm{~V}$; in the successive scan, it is observed that the reduced product formed can be reoxidized (IVa') (Fig. 2c). In the case of compound 38, anodic peak IVa is followed by a more positive one (Va) due to the presence of an electron-donating group. Electrochemical data are displayed in Table 2.

The values of $E_{\mathrm{pIc}}$ varied from $-0.644 \mathrm{~V}$ up to $-0.674 \mathrm{~V}$ (Table 2). As the selenium-phenyl moiety is coupled to the reducible quinone moiety without conjugation, there is only a slight change in the reduction potentials, with compound $\mathbf{4 0}(p-\mathrm{Br})$ being the most easily reduced; the aliphatic selenium derivative is reduced at more negative potentials. The majority of

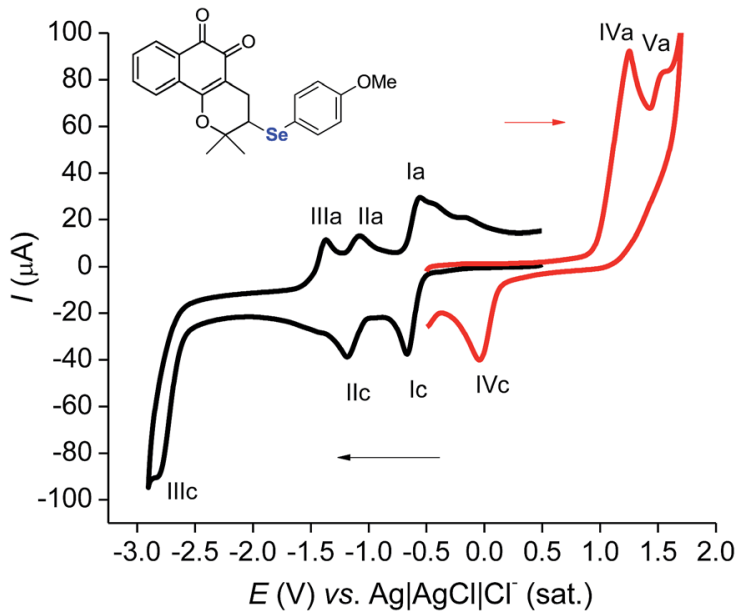

Fig. 2 Cyclic voltammograms (first cycle) of compound 38, in DMF + TBAPF $_{6}\left(0.1 \mathrm{~mol} \mathrm{~L}^{-1}\right)$. Glassy carbon electrode, $\nu=100 \mathrm{mV} \mathrm{s}^{-1},(c=1$ $\mathrm{mmol} \mathrm{L}^{-1}$ ). Black: potential range from $+0.5 \mathrm{~V}$ to $-3.0 \mathrm{~V}$, cathodic direction; red: potential range from $-0.5 \mathrm{~V}$ to $+2.0 \mathrm{~V}$, anodic direction.

selenium-containing $\beta$-lapachone derivatives are voltammetrically interrogated in DMF and displayed only one irreversible oxidation peak between $+1.126 \mathrm{~V}$ and $+1.252 \mathrm{~V} v$ s. $\mathrm{Ag} \mid \mathrm{AgCl}, \mathrm{Cl}^{-}$ (Table 2).

The first monoelectronic transfer leads to the formation of the corresponding Se radical-cation. Three reaction paths are generally available to alkylphenyl chalcogenide radical-cations: deprotonation; nucleophilic attack at the chalcogen atom; and $\mathrm{C}-$ chalcogen bond cleavage. The relative weight of each of these reaction pathways is governed by the nature of the chalcogen and of the alkyl group linked to it, as well as by the nature of the electrolysis medium. ${ }^{61}$

The electrochemical oxidation is shown to follow an overall EC-type mechanism, in which the electro-generated seleniumbased cation radical undergoes an irreversible carbon-chalcogen bond rupture, ${ }^{58}$ similar to the pathway followed by glycosylchalcogenides. ${ }^{59}$ This cleavage produces the corresponding unsaturated quinone, which undergoes reduction in the reverse cycle (wave IVc), together with the intermediate organic selenium radical. The organic selenium radical reacts further to form the selenoxide specie, which can follow several pathways depending on the amount of water in the supporting

Table 2 Main electrochemical parameters for the analysed compounds 36-39, 40, 41, and 45 in DMF + TBAPF $6\left(0.1\right.$ mol L $\left.^{-1}\right)$. Glassy carbon electrode, $\nu=100 \mathrm{mV} \mathrm{s}^{-1}\left(c=1 \mathrm{mmol} \mathrm{L}^{-1}\right)^{a}$

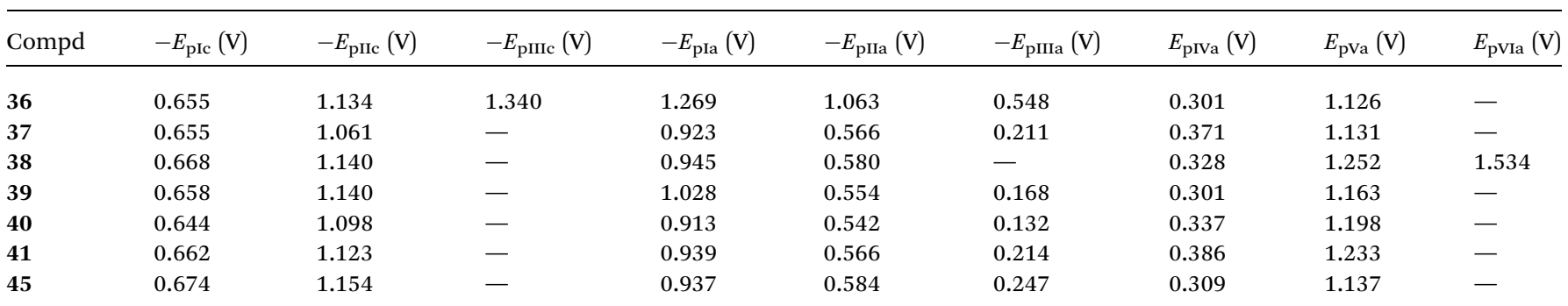

${ }^{a}$ Nd. not determined. 


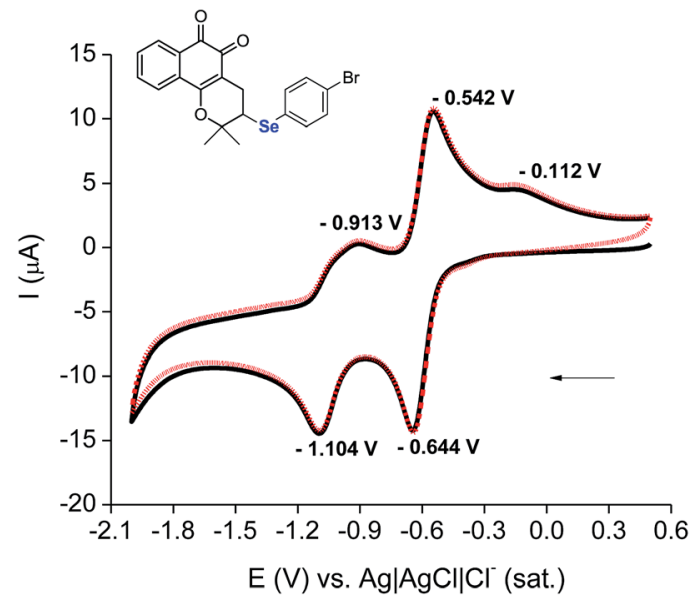

(a)

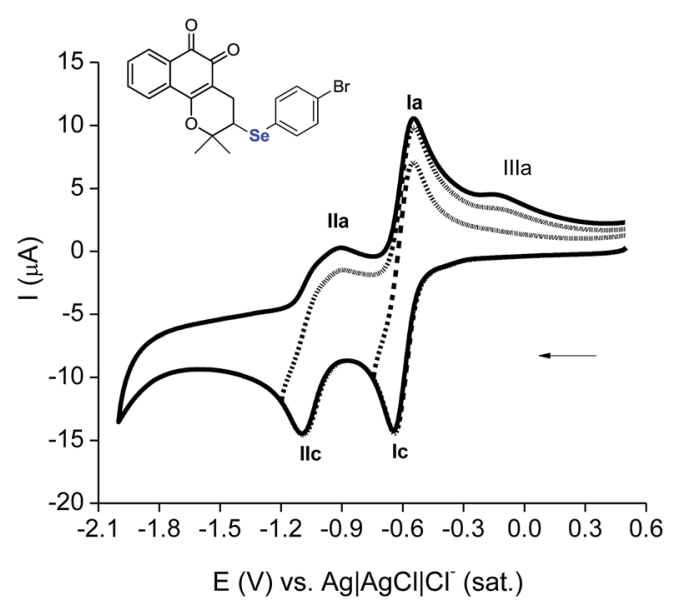

(b)

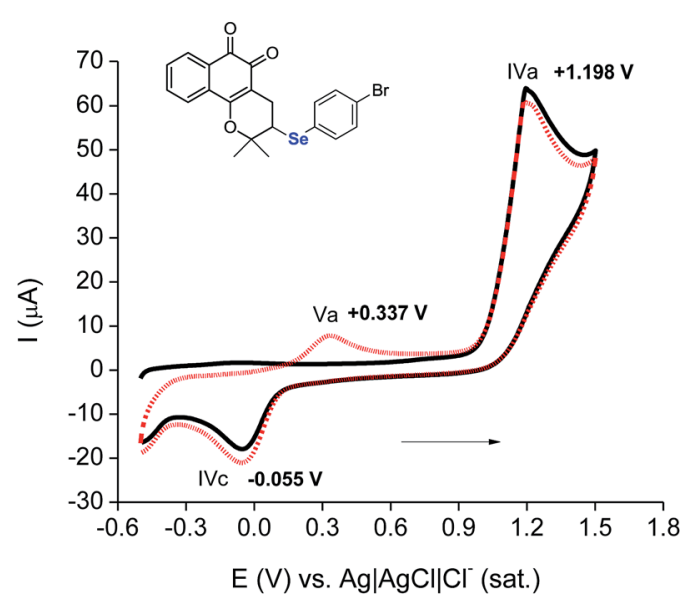

(c)

Fig. 3 Cyclic voltammograms of compound 40 in DMF + TBAPF 6 (0.1 $\left.\mathrm{mol} \mathrm{L}^{-1}\right)$. Glassy carbon electrode, $\nu=100 \mathrm{mV} \mathrm{s}^{-1}\left(c=1 \mathrm{mmol} \mathrm{L}^{-1}\right)$. (a) Potential range from $+0.5 \mathrm{~V}$ to $-2.0 \mathrm{~V}, 2$ successive cycles. (b) Potential range from $+0.5 \mathrm{~V}$ to $-2.0 \mathrm{~V}$, several values for potential inversion. (c) Potential range from $-0.5 \mathrm{~V}$ to $+1.5 \mathrm{~V}, 2$ successive cycles.

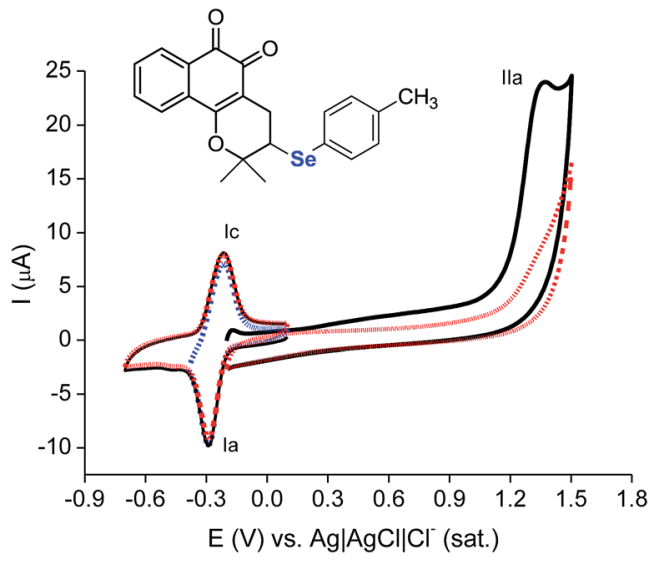

Fig. 4 Cyclic voltammograms of compound 37, in phosphate buffer $(\mathrm{pH} 7.4)+20 \%$ ethanol. Glassy carbon electrode, $\nu=100 \mathrm{mV} \mathrm{s}^{-1},(c=$ $0.1 \mathrm{mmol} \mathrm{L}^{-1}$ ).

electrolyte. ${ }^{57}$ The resulting cathodic wave IVc is a composed one, possibly related to more than one reduction pathway. The mechanism will be further explored and presented elsewhere.

The electrochemical oxidation profile, based on the values of $E_{\mathrm{pVa}}$ (Table 2, column 9), is related to effects of the substituents and the order of oxidation facility was found to be: $36 \sim 37 \sim 45$ $>39>40>41>38$.

We also studied the behaviour of the compounds in protic medium. The two redox centres in compounds 36-39, 40, 41 and $\mathbf{4 5}$ were then analysed by cyclic voltammetry in protic media. The latter assessment provides insight into the oxidation and reduction processes in which compounds might participate both in vitro and in vivo. This medium resembles the hydrophilic regions of the biological matrixes. ${ }^{12,54}$

The CV in protic medium is represented by a reversible peak system (Ic/Ia) in the cathodic region, typical of quinones, ${ }^{62}$ and one irreversible peak (IIa) with at least twice the current intensity in the anodic region. Fig. 4 represents a general electrochemical profile.

The present compounds exhibited two distinct redox behaviours that were indicative of one quinone and one chalcogen centre (Table 3). At pH 7.4, the quinone redox couple ( $E_{\text {pIa }}$ and $\left.E_{\mathrm{pIc}}\right)$ appeared in the range of $-0.260 \mathrm{~V}$ up to $-0.288 \mathrm{~V} v s$. $\mathrm{Ag} \mid \mathrm{AgCl}$, with quasi-reversible characteristics. Regarding the oxidation of chalcogen centres, CVs displayed irreversible oxidation peaks $\left(E_{\text {pIIa }}\right)$ between $+0.707 \mathrm{~V}$ (compound 36) and

Table 3 Main electrochemical parameters for the analysed compounds in phosphate buffer $(\mathrm{pH} 7.4)+20 \%$ ethanol. Glassy carbon electrode, $\nu=100 \mathrm{mV} \mathrm{s}^{-1}\left(c=0.1 \mathrm{mmol} \mathrm{L}^{-1}\right)$

\begin{tabular}{llllll}
\hline Compd & $-E_{\mathrm{pc}_{1}}(\mathrm{~V})$ & $-E_{\mathrm{pc}_{2}}(\mathrm{~V})$ & $-E_{\mathrm{pa}_{1}}(\mathrm{~V})$ & $E_{\mathrm{pa}_{2}}(\mathrm{~V})$ & Others $(\mathrm{V})$ \\
\hline 36 & 0.260 & 0.410 & 0.221 & 0.707 & 0.082 \\
37 & 0.288 & - & 0.215 & 1.362 & - \\
39 & 0.284 & - & 0.189 & 1.460 & 0.278 \\
$\mathbf{4 0}$ & 0.273 & - & 0.209 & 1.336 & 0.171 \\
$\mathbf{4 1}$ & 0.263 & - & 0.205 & 1.445 & - \\
$\mathbf{4 5}$ & 0.269 & - & 0.223 & 1.316 & -
\end{tabular}


$+1.460 \mathrm{~V}$ (compound 39). The oxidation peaks are probably due to the formation of the intermediate radical species, rapidly followed by reaction with water to form the chalcogen oxide. ${ }^{39}$

Overall, cyclic voltammetry confirmed the presence of two individual redox centres. While the centres influenced each other, e.g., via electron withdrawing effects, there was little enhancement or synergy between them. This was not surprising, as there was a substantial difference between the organochalcogen and quinone redox potentials and no conjugation between them.

\section{Conclusions}

We described thirty-eight compounds that were evaluated for their effects on the infective bloodstream form of $T$. cruzi, the etiological agent of Chagas disease. Six compounds were discovered to have potent trypanocidal activity. The quinonebased 1,2,3-triazoles showed the best results in the series, with 4 representatives (26-29) being more active than Bnz. The strategy of preparing a wide range of multifunctional catalysts for generating oxidative stress, with two or even more redox centres combined in chemically simple molecules, was shown to be effective. Based on current assessments, structural aspects and electrochemical parameters do not show correlation with trypanocidal activity. This work represents an important contribution to the discovery of new drugs to combat T. cruzi and therefore provides the impetus for follow-up investigations involving synthetic chemistry, electrochemistry and cell biology.

\section{Experimental section}

\section{General}

Melting points were obtained on a Thomas Hoover apparatus and are uncorrected. Analytical grade solvents were used. Column chromatography was performed on silica gel (SiliaFlash G60 UltraPure - 60-200 $\mu \mathrm{m}, 60 \AA$ ). Infrared spectra were recorded on an FTIR Spectrometer IR Prestige-21 - Shimadzu. ${ }^{1} \mathrm{H}$ - and ${ }^{13} \mathrm{C}-\mathrm{NMR}$ were recorded at room temperature using a Bruker AVANCE DRX200 and DRX 400 in the solvents indicated, with TMS as an internal reference. Chemical shifts $(\delta)$ are given in ppm and coupling constants $(J)$ in Hertz. High-resolution mass spectra (electrospray ionization) were obtained using a Shimadzu LCMS-IT-TOF. Lapachol (1) was extracted from the heartwood of Tabebuia sp. (Tecoma) and purified by a series of recrystallizations. Nor-lapachol (15) was obtained as a crystalline orange solid by Hooker oxidation ${ }^{44}$ of quinone $\mathbf{1}$. Compounds 17-21 and 36-46 were prepared as recently reported by our research group. ${ }^{\mathbf{4 5 , 5 1}}$

\section{Trypanocidal assay}

Stock solutions of the compounds were prepared in dimethyl sulfoxide (DMSO, with the final concentration of the latter in the experiments never exceeding $0.1 \%$ ). Preliminary experiments showed that concentrations of up to $0.5 \%$ DMSO have no deleterious effect on the parasites. Bloodstream trypomastigotes of the Y strain were obtained at the peak of parasitaemia from infected albino mice, isolated by differential centrifugation and resuspended in Dulbecco's modified Eagle medium (DME) to a parasite concentration of $10^{7}$ cells per $\mathrm{mL}$ in the presence of $10 \%$ of mouse blood. This suspension $(100 \mu \mathrm{L}$ was added in the same volume of each compound previously prepared at twice the desired final concentrations). Cell counts were performed in a Neubauer chamber, and the trypanocidal activity was expressed as $\mathrm{IC}_{50}$, corresponding to the concentration that leads to lysis of $50 \%$ of the parasites.

\section{Toxicity to macrophages}

The cytotoxicity assays were performed using primary cultures of peritoneal macrophages obtained from Swiss mice. ${ }^{63}$ For the experiments, $6 \times 10^{4}$ cells in $100 \mathrm{~mL}$ of RPMI-1640 medium ( $\mathrm{pH}$ 7.2 plus $10 \%$ foetal bovine serum and $2 \mathrm{mM}$ glutamine) were added to each well of a 96-well microtiter plate and incubated for $24 \mathrm{~h}$ at $37^{\circ} \mathrm{C}$. The treatment of the cultures was performed in fresh supplemented medium without phenol red $(200 \mu \mathrm{L}$ per well for $24 \mathrm{~h}$ at $37^{\circ} \mathrm{C}$ ). After this period, $110 \mu \mathrm{L}$ of the medium was discarded and $10 \mu \mathrm{L}$ of PrestoBlue (Invitrogen) was added to complete the final volume of $100 \mu \mathrm{L}$. Then, the plate was incubated for $5 \mathrm{~h}$, and the measurement was performed at 570 and $600 \mathrm{~nm}$, as recommended by the manufacturer. The results are expressed as the difference in the percentage of reduction between the treated and untreated cells as the $\mathrm{LC}_{50}$ value, corresponding to the concentration that leads to damage of $50 \%$ of the mammalian cells.

\section{Statistical analysis}

The comparison between the $\mathrm{IC}_{50}$ values for $T$. cruzi was performed using ANOVA followed by the Student-Newman-Keuls and Mann-Whitney tests $(p<0.05)$.

\section{Electrochemical studies}

Cyclic voltammetry (CV) experiments were performed with a conventional three electrode cell in an Autolab PGSTAT-30 potentiostat (Echo Chemie, Utrecht, the Netherlands) coupled to a PC microcomputer, using GPES 4.9 software. The working electrode was a glassy carbon electrode (GCE) BAS $(d=3 \mathrm{~mm})$, the counter electrode was a Pt wire, and the reference electrode was an $\mathrm{Ag} \mid \mathrm{AgCl}, \mathrm{Cl}^{-}$(sat.). All electrodes were contained in a one-compartment electrochemical cell with a volumetric capacity of $10 \mathrm{~mL}$. The GC electrode was cleaned up by polishing with alumina on a polishing felt (BAS polishing kit). The solvent used was $N, N$-dimethylformamide extra dry $99.8 \%$, acquired from Acrós Organics. In CV experiments, the scan rate varied from 10 to $500 \mathrm{mV} \mathrm{s}^{-1}$. Electrochemical reduction was performed in aprotic media $\left(\mathrm{DMF}+\mathrm{TBAPF}_{6} 0.1 \mathrm{~mol} \mathrm{~L}^{-1}\right)$ at room temperature $\left(25 \pm 2{ }^{\circ} \mathrm{C}\right)$. Each compound $\left(1 \times 10^{-3} \mathrm{~mol}\right.$ $\mathrm{L}^{-1}$ ) was added to the supporting electrolyte, and the solution was deoxygenated with argon before the CV measurements. Different potential ranges were used from the cathodic to anodic scan. The most representative range was from 0 to -3.0 $\mathrm{V}$ vs. $\mathrm{Ag} \mid \mathrm{AgCl}, \mathrm{Cl}^{-}$(sat.) and was chosen for the investigation 
and representation of all the compounds. Anodic scans until $+1.0 \mathrm{~V}$ were performed.

\section{General procedure for the synthesis of compounds 3-14}

To a mixture of $242 \mathrm{mg}(1.0 \mathrm{mmol})$ of 2 and $267 \mathrm{mg}(1.5 \mathrm{mmol})$ of $N$-bromosuccinimide in $30 \mathrm{~mL}$ of $\mathrm{CCl}_{4}, 2 \mathrm{mg}$ of benzoyl peroxide was added. The mixture was heated $\left(80^{\circ} \mathrm{C}\right)$ for five hours. The $\mathrm{CCl}_{4}$ was then removed by reduce pressure and 25 $\mathrm{mL}$ of dichloromethane and the corresponding aniline was added. The resulting mixture was stirred overnight at room temperature. The crude material was then submitted to column chromatography utilizing a mixture of ethyl acetate/hexane as an eluent.

4-((4-Fluorophenyl)amino)-2,2-dimethyl-3,4-dihydro-2Hbenzo[g]chromene-5,10-dione (8). Compound 8 was obtained as an orange solid (210 mg, $0.6 \mathrm{mmol}, 60 \%$ yield); $\mathrm{mp} 173-175{ }^{\circ} \mathrm{C}$. ${ }^{1} \mathrm{H}$ NMR (200 MHz, $\mathrm{CDCl}_{3}$ ) $\delta: 8.08-8.01(\mathrm{~m}, 2 \mathrm{H}), 7.79-7.62(\mathrm{~m}$, $2 \mathrm{H})$, 7.02-6.93 (m, 2H), 6.76-6.69 (m, 2H), 4.68-4.58 (m, 2H), $2.24(\mathrm{dd}, 1 \mathrm{H}, J=3.7$ and $14.3 \mathrm{~Hz}), 2.01(\mathrm{dd}, 1 \mathrm{H}, J=5.3$ and 14.3 $\mathrm{Hz}), 1.56(\mathrm{~s}, 3 \mathrm{H}), 1.51(\mathrm{~s}, 3 \mathrm{H}) .{ }^{13} \mathrm{C} \mathrm{NMR}\left(50 \mathrm{MHz} \mathrm{CDCl}_{3}\right) \delta: 184.3$, 180.2, 155.8, 143.1, 134.7, 133.6, 132.4, 131.1, 128.9, 127.4, 126.7 $(\mathrm{d}, J=11.2 \mathrm{~Hz}), 119.1,116.4,116.1(\mathrm{~d}, J=10.2 \mathrm{~Hz}), 116.0,79.6$, 65.7, 45.1, 37.8, 28.8, 26.8. ESI-MS: $(\mathrm{m} / \mathrm{z})\left[\mathrm{C}_{21} \mathrm{H}_{18} \mathrm{FNO}_{3}\right]^{+}$: 351.1270. Cald. for $\left[\mathrm{C}_{21} \mathrm{H}_{18} \mathrm{FNO}_{3}\right]^{+}: 351.1271$.

4-((3-Iodophenyl)amino)-2,2-dimethyl-3,4-dihydro-2H-benzo[g]chromene-5,10-dione (11). Compound 11 was obtained as a brown solid (321 mg, $0.7 \mathrm{mmol}, 70 \%$ yield); mp 190-192 ${ }^{\circ} \mathrm{C} .{ }^{1} \mathrm{H}$ NMR (200 $\mathrm{MHz} \mathrm{CDCl}_{3}$ ) $\delta:$ 7.97-7.93 (m, 2H), 7.67-7.63 (m, 2H), 7.04-6.96 (m, $1 \mathrm{H}), 6.88(\mathrm{t}, 1 \mathrm{H}, J=7.9 \mathrm{~Hz}), 6.65(\mathrm{~d}, 1 \mathrm{H}, J=7.9 \mathrm{~Hz}), 4.68(\mathrm{~s}, 1 \mathrm{H})$, $4.61(\mathrm{~s}, 1 \mathrm{H}), 2.25$ (dd, $1 \mathrm{H}, J=3.7$ and $14.3 \mathrm{~Hz}), 1.96(\mathrm{dd}, 1 \mathrm{H}, J=5.3$ and $14.3 \mathrm{~Hz}$ ), $1.53(\mathrm{~s}, 6 \mathrm{H}) .{ }^{13} \mathrm{C} \mathrm{NMR}\left(50 \mathrm{MHz}, \mathrm{CDCl}_{3}\right) \delta: 183.4$, 179.7, 155.3, 148.0, 134.3, 133.2, 131.8, 130.7, 128.4, 126.9, 126.3, 126.0, 121.9, 118.3, 112.8, 95.3, 79.1, 42.9, 37.1, 29.0, 26.0. ESI-MS: $(m / z)\left[\mathrm{C}_{21} \mathrm{H}_{18} \mathrm{INO}_{3} \mathrm{Na}\right]^{+}$: 482.0433. Cald. for $\left[\mathrm{C}_{21} \mathrm{H}_{18} \mathrm{INO}_{3} \mathrm{Na}\right]^{+}$: 482.0229 .

4-((3-Chlorophenyl)amino)-2,2-dimethyl-3,4-dihydro- $2 \mathrm{H}$ benzo[g]chromene-5,10-dione (12). Compound 12 was obtained as a yellow solid (220 mg, $0.6 \mathrm{mmol}, 60 \%$ yield); $\mathrm{mp} 177-179{ }^{\circ} \mathrm{C}$. ${ }^{1} \mathrm{H}$ NMR $\left(200 \mathrm{MHz}, \mathrm{CDCl}_{3}\right) \delta: 8.06-7.97(\mathrm{~m}, 2 \mathrm{H}), 7.72-7.63(\mathrm{~m}$, $2 \mathrm{H})$, 7.11-7.07 (m, 1H), 6.77-6.63 (m, 2H), 6.58-6.56 (m, 1H), $4.65(\mathrm{~s}, 1 \mathrm{H}), 2.26(\mathrm{dd}, 1 \mathrm{H}, J=2.7$ and $14.4 \mathrm{~Hz}), 1.99(\mathrm{dd}, 1 \mathrm{H}, J=$ 5.2 and $14.4 \mathrm{~Hz}), 1.54(\mathrm{~s}, 3 \mathrm{H}), 1.53(\mathrm{~s}, 3 \mathrm{H}) .{ }^{13} \mathrm{C}$ NMR $(50 \mathrm{MHz}$, $\left.\mathrm{CDCl}_{3}\right) \delta: 183.4,179.7,155.3,148.1,135.0,134.3,133.2,132.0$, 130.8, 130.2 , 126.3, 126.1, 118.5, 117.9, 113.1, 111.8, 79.0, 43.11, 37.4, 28.9, 26.1. ESI-MS: $(\mathrm{m} / \mathrm{z})\left[\mathrm{C}_{21} \mathrm{H}_{18} \mathrm{ClNO}_{3}\right]^{+}:$367.0962. Cald. for $\left[\mathrm{C}_{21} \mathrm{H}_{18} \mathrm{ClNO}_{3}\right]^{+}: 367.0975$.

4-((3-Methoxyphenyl)amino)-2,2-dimethyl-3,4-dihydro-2Hbenzo $[g]$ chromene-5,10-dione (13). Compound 13 was obtained as a brown solid (254 mg, $0.7 \mathrm{mmol}, 70 \%$ yield); mp 88-90 ${ }^{\circ} \mathrm{C}$. ${ }^{1} \mathrm{H}$ NMR (200 MHz, $\mathrm{CDCl}_{3}$ ) $\delta: 7.92-7.91(\mathrm{~m}, 2 \mathrm{H}), 7.70-7.53(\mathrm{~m}$, $2 \mathrm{H}), 7.06(\mathrm{t}, 1 \mathrm{H}, J=7.9 \mathrm{~Hz}), 6.42-6.18(\mathrm{~m}, 3 \mathrm{H}), 4.63(\mathrm{~s}, 1 \mathrm{H}), 3.73$ $(\mathrm{s}, 3 \mathrm{H}), 2.28(\mathrm{dd}, 1 \mathrm{H}, J=2.7$ and $14.4 \mathrm{~Hz}), 1.92(\mathrm{dd}, 1 \mathrm{H}, J=5.2$ and $14.4 \mathrm{~Hz}), 1.53(\mathrm{~s}, 3 \mathrm{H}), 1.49(\mathrm{~s}, 3 \mathrm{H}) .{ }^{13} \mathrm{C}$ NMR $(50 \mathrm{MHz}$, $\left.\mathrm{CDCl}_{3}\right) \delta: 183.3,179.7,160.7,155.1,148.2$, 134.2, 133.1, 131.9, 130.6, 130.0, 126.2, 126.0, 118.8, 106.6, 103.0, 99.6, 79.0, 55.0,
43.0, 37.2, 28.9, 26.1. ESI-MS: $(\mathrm{m} / \mathrm{z})\left[\mathrm{C}_{22} \mathrm{H}_{21} \mathrm{NO}_{4} \mathrm{H}\right]^{+}: 364.143$. Cald. for $\left[\mathrm{C}_{22} \mathrm{H}_{21} \mathrm{NO}_{4} \mathrm{H}\right]^{+}$: 364.1549 .

\section{General procedure for the synthesis of compounds 25-29}

To a mixture of $255 \mathrm{mg}(1.0 \mathrm{mmol})$ of $24, \mathrm{CuSO}_{4} \cdot 5 \mathrm{H}_{2} \mathrm{O}(12.48$ $\mathrm{mg}, 5 \mathrm{~mol} \%$ ) and sodium ascorbate $(19.81 \mathrm{mg}, 5 \mathrm{~mol} \%)$ in $8 \mathrm{~mL}$ $\mathrm{CH}_{2} \mathrm{Cl}_{2} / \mathrm{H}_{2} \mathrm{O}(1: 1 \mathrm{v} / \mathrm{v})$, the corresponding alkyne (1.1 equivalents) was added. The mixture was stirred overnight at room temperature. The organic phase was extracted with dichloromethane, dried with $\mathrm{NaSO}_{4}$ and concentrated under reduced pressure. The residue obtained was purified by column chromatography on silica gel using as eluent a gradient mixture of hexane/ethyl acetate with increasing polarity.

2-((4-Cyclohexyl-1H-1,2,3-triazol-1-yl)methyl)-2,3-dihydronaphtho[1,2-b]furan-4,5-dione (25). Using ethynylcyclohexane $(118 \mathrm{mg}$, $1.1 \mathrm{mmol}), 25$ was obtained as a red solid $(298 \mathrm{mg}, 0.82 \mathrm{mmol}$, $82 \%$ yield); mp $163-164{ }^{\circ} \mathrm{C} .{ }^{1} \mathrm{H}$ NMR $\left(400 \mathrm{MHz} \mathrm{CDCl}_{3}\right) \delta: 8.05$ (d, $1 \mathrm{H}, J=7.4 \mathrm{~Hz}), 7.70-7.66(\mathrm{~m}, 1 \mathrm{H}), 7.62-7.58(\mathrm{~m}, 2 \mathrm{H}), 7.54(\mathrm{~s}, 1 \mathrm{H})$, $6.52(\mathrm{~s}, 1 \mathrm{H}), 5.56-5.49(\mathrm{~m}, 1 \mathrm{H}), 4.80-4.68(\mathrm{~m}, 2 \mathrm{H}), 3.40-3.28(\mathrm{~m}$, $1 \mathrm{H}), 2.97(\mathrm{dd}, 1 \mathrm{H}, J=6.9$ and $15.6 \mathrm{~Hz}), 2.42-2.31(\mathrm{~m}, 2 \mathrm{H}), 2.27-$ $2.13(\mathrm{~m}, 4 \mathrm{H}), 1.84-1.62(\mathrm{~m}, 4 \mathrm{H}) .{ }^{13} \mathrm{C} \mathrm{NMR}\left(100 \mathrm{MHz}, \mathrm{CDCl}_{3}\right) \delta$ : 180.5, 175.2 , 168.9, 149.9, 134.7, 132.3, 130.6, 129.7, 127.0, 125.7, 124.4 , 119.2 , 114.8, 84.6, 53.2, 30.9, 29.6, 26.3, 25.3, 22.4, 22.1. ESIMS: $(\mathrm{m} / \mathrm{z})\left[\mathrm{C}_{21} \mathrm{H}_{21} \mathrm{~N}_{3} \mathrm{O}_{3}\right]^{-}:$362.1893. Cald. for $\left[\mathrm{C}_{21} \mathrm{H}_{21} \mathrm{~N}_{3} \mathrm{O}_{3}\right]^{-}$: 362.1510 .

2-((4-(1-Hydroxycyclohexyl)-1H-1,2,3-triazol-1-yl)methyl)-2,3dihydronaphtho[1,2-b]furan-4,5-dione (26). Using 1-ethynylcyclohexanol (136 mg, $1.1 \mathrm{mmol}$ ), 26 was obtained as a red solid (345 mg, $0.91 \mathrm{mmol}, 90 \%$ yield); mp 92-93 ${ }^{\circ} \mathrm{C} .{ }^{1} \mathrm{H}$ NMR (400 $\left.\mathrm{MHz}, \mathrm{CDCl}_{3}\right) \delta: 8.03(\mathrm{~d}, 1 \mathrm{H}, J=7.2 \mathrm{~Hz}), 7.71-7.64(\mathrm{~m}, 2 \mathrm{H}), 7.61-$ $7.58(\mathrm{~m}, 2 \mathrm{H}), 5.56-5.50(\mathrm{~m}, 1 \mathrm{H}), 4.82-4.69(\mathrm{~m}, 2 \mathrm{H}), 3.36-3.30$ $(\mathrm{m}, 1 \mathrm{H}), 2.98(\mathrm{dd}, 1 \mathrm{H}, J=6.7$ and $15.7 \mathrm{~Hz}), 2.17(\mathrm{~s}, 1 \mathrm{H}), 2.02-$ $1.92(\mathrm{~m}, 2 \mathrm{H}), 1.89-1.78$ (m, 2H), 1.76-1.68 (m, 2H), 1.54-1.47 $(\mathrm{m}, 2 \mathrm{H}), 1.36-1.24(\mathrm{~m}, 2 \mathrm{H}) .{ }^{13} \mathrm{C} \mathrm{NMR}\left(100 \mathrm{MHz} \mathrm{CDCl}_{3}\right) \delta: 180.4$, 175.1 , 168.9, 134.8, 132.3, 130.5, 129.7, 126.9, 124.5, 120.9, 114.8, 84.5, 69.6, 53.4, 38.1, 38.0, 29.6, 25.3, 22.0. ESI-MS: $(\mathrm{m} / \mathrm{z})$ $\left[\mathrm{C}_{21} \mathrm{H}_{21} \mathrm{~N}_{3} \mathrm{O}_{4} \mathrm{Na}\right]^{+}:$402.1518. Cald. for $\left[\mathrm{C}_{21} \mathrm{H}_{21} \mathrm{~N}_{3} \mathrm{O}_{4} \mathrm{Na}\right]^{+}$: 402.1424 .

2-((4-(((Tetrahydro-2H-pyran-2-yl)oxy)methyl)-1H-1,2,3-triazol-1-yl)methyl)-2,3-dihydronaphtho[1,2-b]furan-4,5-dione (27). Using 2-(prop-2-yn-1-yloxy)tetrahydro-2 $H$-pyran (154 mg, 1.1 $\mathrm{mmol}$ ), 27 was obtained as a red solid (324 mg, $0.82 \mathrm{mmol}, 82 \%$ yield); mp 86-87 ${ }^{\circ} \mathrm{C} .{ }^{1} \mathrm{H}$ NMR (400 MHz, $\left.\mathrm{CDCl}_{3}\right) \delta: 8.02$ (d, $1 \mathrm{H}, J=$ $7.1 \mathrm{~Hz}), 7.72(\mathrm{~s}, 1 \mathrm{H}), 7.67-7.63(\mathrm{~m}, 1 \mathrm{H}), 7.59-7.56(\mathrm{~m}, 2 \mathrm{H}), 5.56-$ $5.49(\mathrm{~m}, 1 \mathrm{H}), 4.89-4.64(\mathrm{~m}, 6 \mathrm{H}), 3.90-3.82(\mathrm{~m}, 1 \mathrm{H}), 3.54-3.51(\mathrm{~m}$, $1 \mathrm{H}), 3.37-3.30(\mathrm{~m}, 1 \mathrm{H}), 2.97-2.91(\mathrm{~m}, 1 \mathrm{H}), 1.80-1.66(\mathrm{~m}, 2 \mathrm{H})$, 1.57-1.50 (m, 3H). ${ }^{13} \mathrm{C}$ NMR (100 MHz, $\left.\mathrm{CDCl}_{3}\right) \delta: 180.4,175.2$, 134.7, 132.3, 130.6, 129.7, 126.9, 124.5, 123.6, 114.8, 98.3, 98.3, 84.5, 62.5, 60.5, 53.3, 30.9, 30.4, 29.6, 25.3, 19.4. ESI-MS: $(\mathrm{m} / \mathrm{z})$ $\left[\mathrm{C}_{21} \mathrm{H}_{21} \mathrm{~N}_{3} \mathrm{O}_{5} \mathrm{Na}\right]^{+}:$418.1016. Cald. for $\left[\mathrm{C}_{21} \mathrm{H}_{21} \mathrm{~N}_{3} \mathrm{O}_{5} \mathrm{Na}\right]^{+}: 418.1379$.

2-((4-(Cyclohex-1-en-1-yl)-1H-1,2,3-triazol-1-yl)methyl)-2,3dihydronaphtho[1,2-b]furan-4,5-dione (28). Using 1ethynylcyclohex-1-ene (116 mg, $1.1 \mathrm{mmol}), 28$ was obtained as a red solid (336 mg, $0.93 \mathrm{mmol}$, 93\% yield); mp $112-113{ }^{\circ} \mathrm{C} .{ }^{1} \mathrm{H}$ NMR (400 MHz, $\left.\mathrm{CDCl}_{3}\right) \delta: 8.03(\mathrm{~d}, 1 \mathrm{H}, J=7.4 \mathrm{~Hz}), 7.70-7.66(\mathrm{t}$, $1 \mathrm{H}, J=16.3 \mathrm{~Hz}), 7.61-7.54(\mathrm{~m}, 2 \mathrm{H}), 7.54(\mathrm{~s}, 1 \mathrm{H}), 6.55-6.49(\mathrm{~m}$, 
1H), 5.56-5.49 (m, 1H), 4.80-4.68 (m, 2H), 3.33 (dd, 1H, J=10.2 and $15.7 \mathrm{~Hz}), 2.96(\mathrm{dd}, 1 \mathrm{H}, J=7.0$ and $15.7 \mathrm{~Hz}), 2.41-2.16(\mathrm{~m}$, $3 \mathrm{H}), 1.82-1.61(\mathrm{~m}, 4 \mathrm{H}), 0.92-0.83(\mathrm{~m}, 1 \mathrm{H}) .{ }^{13} \mathrm{C}$ NMR $(100 \mathrm{MHz}$, $\left.\mathrm{CDCl}_{3}\right) \delta: 180.5,175.2,168.9,149.9,134.8,132.3,130.6,129.7$, 127.0, 125.7, 124.5, 119.2, 114.8, 84.6, 53.2, 29.6, 26.3, 25.3, 22.4, 22.1. ESI-MS: $(\mathrm{m} / \mathrm{z}) \quad\left[\mathrm{C}_{21} \mathrm{H}_{20} \mathrm{~N}_{3} \mathrm{O}_{3}\right]^{+}:$362.1978. Cald. for $\left[\mathrm{C}_{21} \mathrm{H}_{20} \mathrm{~N}_{3} \mathrm{O}_{3}\right]^{+}: 362.1499$.

2-((4-Hexyl-1H-1,2,3-triazol-1-yl)methyl)-2,3-dihydronaphtho[1,2-b]furan-4,5-dione (29). Using oct-1-yne (121 mg, $1.1 \mathrm{mmol}$ ), 29 was obtained as a red solid (332 $\mathrm{mg}, 0.91 \mathrm{mmol}, 91 \%$ yield); mp 121-123 ${ }^{\circ} \mathrm{C} .{ }^{1} \mathrm{H}$ NMR (400 MHz, $\left.\mathrm{CDCl}_{3}\right) \delta: 8.04$ (d, $1 \mathrm{H}, J=8.2$ $\mathrm{Hz}), 7.67(\mathrm{t}, 1 \mathrm{H}, J=7.4 \mathrm{~Hz}), 7.59-7.57(\mathrm{~m}, 2 \mathrm{H}), 7.45(\mathrm{~s}, 1 \mathrm{H}), 5.57-$ $5.49(\mathrm{~m}, 1 \mathrm{H}), 4.81-4.69(\mathrm{~m}, 2 \mathrm{H}), 3.31(\mathrm{dd}, 1 \mathrm{H}, J=10.2$ and 15.7 $\mathrm{Hz}), 2.96(\mathrm{dd}, 1 \mathrm{H}, J=6.9$ and $15.7 \mathrm{~Hz}), 2.72(\mathrm{t}, 2 \mathrm{H}, J=7.2 \mathrm{~Hz})$, 1.67-1.60 (m, 2H), 1.35-1.28 (m, 6H), 0.89-0.86 (m, 3H). ${ }^{13} \mathrm{C}$ NMR $\left(100 \mathrm{MHz}, \mathrm{CDCl}_{3}\right) \delta: 180.5,175.1,168.9,148.9,134.7$, 132.3, 130.5, 129.7, 126.9, 124.4, 121.6, 114.8, 84.7, 53.2, 31.5, 29.6, 29.3, 28.8, 25.6, 22.5, 14.1. ESI-MS: $(\mathrm{m} / \mathrm{z})\left[\mathrm{C}_{21} \mathrm{H}_{24} \mathrm{~N}_{3} \mathrm{O}_{3}\right]^{+}$: 366.2340. Cald. for $\left[\mathrm{C}_{21} \mathrm{H}_{24} \mathrm{~N}_{3} \mathrm{O}_{3}\right]^{+}: 366.1812$.

\section{General procedure for the synthesis of compounds 30,31 and} 33-35

To a mixture of $256 \mathrm{mg}$ ( $1 \mathrm{mmol})$ of 24 or $269 \mathrm{mg}(1.0 \mathrm{mmol})$ of 32 with $\mathrm{CuSO}_{4} \cdot 5 \mathrm{H}_{2} \mathrm{O}(12.48 \mathrm{mg}, 5 \mathrm{~mol} \%)$ and sodium ascorbate (19.81 $\mathrm{mg}, 5 \mathrm{~mol} \%$ ) in $8 \mathrm{~mL} \mathrm{CH}_{2} \mathrm{Cl}_{2} / \mathrm{H}_{2} \mathrm{O}(1: 1 \mathrm{v} / \mathrm{v})$, the corresponding alkyne-carbohydrate ( 1.1 equivalents) was added. The mixture was stirred overnight at room temperature. The organic phase was extracted with dichloromethane, dried with $\mathrm{NaSO}_{4}$ and concentrated under reduced pressure. The residue obtained was purified by column chromatography on silica gel using as eluent a gradient mixture of hexane/ethyl acetate with increasing polarity. The products 33-35 were obtained as diastereomers (diastereomer ratio $1: 1)$.

$(2 S, 3 S, 4 R, 5 S, 6 S)$-2-(Acetoxymethyl)-6-((1-((4,5-dioxo-2,3,4,5-tetrahydronaphtho[1,2-b]furan-2-yl)methyl)-1H-1,2,3-triazol-4-yl)methoxy)tetrahydro-2H-pyran-3,4,5-triyl triacetate (30). Using $(2 R, 3 R, 4 S, 5 R, 6 R)$-2-(acetoxymethyl)-6-(prop-2-yn-1-yloxy)tetrahydro- $2 H$-pyran-3,4,5-triyl triacetate $(424 \mathrm{mg}, 1.1 \mathrm{mmol}), 30$ was obtained as a yellow solid ( $544 \mathrm{mg}, 0.8 \mathrm{mmol}, 85 \%$ yield); $\mathrm{mp}$ 117-119 ${ }^{\circ} \mathrm{C} .{ }^{1} \mathrm{H}$ NMR $\left(400 \mathrm{MHz}, \mathrm{CDCl}_{3}\right) \delta: 8.06$ (bs, 1H), 7.767.67 (m, 2H), 7.61-7.59 (bs, 2H), 5.53-5.48 (m, 1H), 5.25-4.70 $(\mathrm{m}, 8 \mathrm{H}), 4.25-4.15(\mathrm{~m}, 2 \mathrm{H}), 3.77(\mathrm{~d}, 1 \mathrm{H}, J=4 \mathrm{~Hz}), 3.38-3.32(\mathrm{~m}$, $1 \mathrm{H}), 2.98-2.93(\mathrm{~m}, 1 \mathrm{H}), 2.08(\mathrm{~s}, 3 \mathrm{H}), 2.04(\mathrm{~s}, 3 \mathrm{H}), 2.01(\mathrm{~s}, 3 \mathrm{H})$, 1.97 (s, 3H). ${ }^{13} \mathrm{C}$ NMR (100 MHz, $\left.\mathrm{CDCl}_{3}\right) \delta: 180.4,178.7,175.2$, $173.8,170.6,170.1,169.4,144.7,134.9,132.4,130.5,129.7$, 126.8, 124.6, 123.8, 114.7, 100.0, 84.5, 72.7, 72.0, 71.2 , 68.3, 63.2, 61.8, 53.4, 29.7, 20.7, 20.7, 20.6, 20.6. ESI-MS: $(\mathrm{m} / \mathrm{z})$ $\left[\mathrm{C}_{30} \mathrm{H}_{31} \mathrm{~N}_{3} \mathrm{O}_{13} \mathrm{Na}\right]^{+}$: 664.1768. Cald. for $\left[\mathrm{C}_{30} \mathrm{H}_{31} \mathrm{~N}_{3} \mathrm{O}_{13} \mathrm{Na}\right]^{+}$: 664.1755 .

$(2 R, 3 S, 4 S, 5 R, 6 R)-2$-(Acetoxymethyl)-6-((1-((4,5-dioxo-2,3,4,5-tetrahydronaphtho[1,2- $b]$ furan-2-yl)methyl)-1H-1,2,3-triazol-4-yl)methoxy)tetrahydro-2H-pyran-3,4,5-triyl triacetate (31). Using $(2 R, 3 S, 4 S, 5 R, 6 R)$-2-(acetoxymethyl)-6-(prop-2-yn-1-yloxy)tetrahydro- $2 H$-pyran-3,4,5-triyl triacetate, 31 was obtained as a yellow solid (512 mg, $0.8 \mathrm{mmol}, 80 \%$ yield); mp 121-122 ${ }^{\circ} \mathrm{C} .{ }^{1} \mathrm{H}$ NMR $\left(400 \mathrm{MHz}, \mathrm{CDCl}_{3}\right) \delta: 8.09$ (bs, 1H), 7.73-7.69 (m, 2H), 7.63-7.58 (m, 2H), 5.55-5.44 (m, 1H), $5.39(\mathrm{~s}, 1 \mathrm{H}), 5.26-5.15(\mathrm{~m}, 1 \mathrm{H}), 5.06-$ 4.95 (m, 2H), 4.81-4.67 (m, 4H), 4.20-4.12 (m, 2H), 3.98 (s, 1H), 3.39-3.33 (m, 1H), 2.98-2.93 (m, 1H), $2.15(\mathrm{~s}, 3 \mathrm{H}), 2.06(\mathrm{~s}, 3 \mathrm{H})$, 1.99 (s, 6H). ${ }^{13} \mathrm{C}$ NMR $\left(100 \mathrm{MHz}, \mathrm{CDCl}_{3}\right) \delta: 180.4,175.3,171.1$, $170.1,170.0,169.6,169.5,144.8,134.9,132.4,130.6,129.8$, 126.9, 124.6, 123.6, 114.7, 100.0, 84.6, 70.9, 70.8, 68.8, 67.1, 63.0, 61.2, 60.4, 53.1, 29.7, 21.0, 20.6, 20.5, 19.0, 14.2. ESI-MS: $(\mathrm{m} / \mathrm{z})$ $\left[\mathrm{C}_{30} \mathrm{H}_{31} \mathrm{~N}_{3} \mathrm{O}_{13} \mathrm{Na}\right]^{+}:$664.1762. Cald. for $\left[\mathrm{C}_{30} \mathrm{H}_{31} \mathrm{~N}_{3} \mathrm{O}_{13} \mathrm{Na}\right]^{+}$: 664.1755 .

$(2 R, 3 R, 4 S, 5 R, 6 R)-2-(A c e t o x y m e t h y l)-6-((1-(2,2-d i m e t h y l-4,5-$ dioxo-2,3,4,5-tetrahydronaphtho[1,2-b]furan-3-yl)-1H-1,2,3-triazol-4-yl)methoxy)tetrahydro-2H-pyran-3,4,5-triyl triacetate (33). Using ( $2 R, 3 R, 4 S, 5 R, 6 R)$-2-(acetoxymethyl)-6-(prop-2-yn-1-yloxy)tetrahydro- $2 H$-pyran-3,4,5-triyl triacetate ( $424 \mathrm{mg}, 1.1 \mathrm{mmol}), 33$ was obtained as a yellow solid (537 $\mathrm{mg}, 0.82 \mathrm{mmol}, 82 \%$ yield); mp 88-90 ${ }^{\circ} \mathrm{C} .{ }^{1} \mathrm{H}$ NMR (400 MHz, $\left.\mathrm{CDCl}_{3}\right) \delta: 8.20-8.17(\mathrm{~m}, 1 \mathrm{H})$, 7.82-7.71 (m, 3H), 7.55/7.51 (s, 1H), 5.98/5.97 (s, 1H), 5.25-5.15 $(\mathrm{m}, 1 \mathrm{H}), 5.07(\mathrm{t}, 1 \mathrm{H}, J=10 \mathrm{~Hz}), 5.00-4.78(\mathrm{~m}, 3 \mathrm{H}), 4.67(\mathrm{t}, 1 \mathrm{H}, J=$ $7.6 \mathrm{~Hz}), 4.30-4.10(\mathrm{~m}, 2 \mathrm{H}), 3.77-3.70(\mathrm{~m}, 1 \mathrm{H}), 2.07,2.01,2.00$, 1.98, 1.97, 1.77 (six singlets observed, 12H), 1.19 (s, 3H), 0.98$0.83(\mathrm{~m}, 3 \mathrm{H}) .{ }^{13} \mathrm{C} \mathrm{NMR}\left(100 \mathrm{MHz}, \mathrm{CDCl}_{3}\right) \delta: 180.0,180.0,174.6$, $174.5,171.3,171.2$, 170.7, 170.6, 170.1, 170.1, 169.6, 169.5, $169.4,144.4,144.2$, 134.8, 134.8, 133.4, 133.4, 131.6, 131.5, $130.0,130.0,126.6,126.6,125.6,125.5,122.6,122.3,111.1$, 100.2, 99.9, 95.9, 95.8, 72.8, 72.6, 71.9, 71.3, 71.2, 68.3, 68.3, 67.0, 66.9, 63.3, 63.0, 61.8, 61.7, 31.5, 29.0, 27.7, 27.6, 22.6, 22.6, $21.1,20.7,20.6,20.5,20.5,20.4,14.1,11.4$. ESI-MS: $(\mathrm{m} / \mathrm{z})$ $\left[\mathrm{C}_{31} \mathrm{H}_{33} \mathrm{~N}_{3} \mathrm{O}_{13} \mathrm{Na}\right]^{+}$: 678.1925. Cald. for $\left[\mathrm{C}_{31} \mathrm{H}_{33} \mathrm{~N}_{3} \mathrm{O}_{13} \mathrm{Na}\right]^{+}$: 678.1911 .

$(2 R, 3 S, 4 S, 5 R, 6 R)-2-($ Acetoxymethyl)-6-((1-(2,2-dimethyl-4,5dioxo-2,3,4,5-tetrahydronaphtho[1,2-b]furan-3-yl)-1H-1,2,3-triazol-4-yl)methoxy)tetrahydro- $2 \mathrm{H}$-pyran-3,4,5-triyl triacetate (34). Using (2R,3S,4S,5R,6R)-2-(acetoxymethyl)-6-(prop-2-yn-1yloxy)tetrahydro- $2 H$-pyran-3,4,5-triyl triacetate $(424 \mathrm{mg}, 1.1$ $\mathrm{mmol}$ ), 34 was obtained as a yellow solid (543 $\mathrm{mg}, 0.83 \mathrm{mmol}$, $83 \%$ yield); $\mathrm{mp} 118-119{ }^{\circ} \mathrm{C} .{ }^{1} \mathrm{H}$ NMR (400 MHz, $\left.\mathrm{CDCl}_{3}\right) \delta: 8.20$ / $8.18(\mathrm{~s}, 1 \mathrm{H}), 7.88-7.78(\mathrm{~m}, 3 \mathrm{H}), 7.60(\mathrm{~s}, 1 \mathrm{H}), 5.99 / 5,98(\mathrm{~s}, 1 \mathrm{H})$, 5.33-5.20 (m, 3H), 4.95-4.80 (m, 2H), 4.77-4.66 (m, 1H), 4.3 (dd, $1 \mathrm{H}, J=12$ and $4.8 \mathrm{~Hz}), 4.18-4.00(\mathrm{~m}, 2 \mathrm{H}), 2.09,1.97,1.95,1.78$ (four singlets observed, 12H), 1.24/1.23 (s, 3H), 0.90-0.84 (m, $3 \mathrm{H}) .{ }^{13} \mathrm{C} \mathrm{NMR}\left(100 \mathrm{MHz}, \mathrm{CDCl}_{3}\right) \delta: 180.0,174.6,171.4,171.3$, $170.7,170.2$, 170.0, 170.0, 169.7, 143.6, 134.8, 134.7, 133.4, $131.6,131.6,130.0,129.9,126.7,126.6,125.7,122.4,122.3$, 111.1, 111.1, 97.1, 96.8, 95.9, 95.9, 69.5, 69.5, 69.0, 68.8, 68.7, 67.0, 67.0, 66.1, 66.0, 62.4, 62.3, 61.4, 61.3, 36.1, 34.6, 31.6, 29.0, 27.7, 27.7, 22.6, 22.6, 22.1, 21.3, 20.8, 20.7, 20.6, 20.4, 18.7, 14.1, 11.4. ESI-MS: $(\mathrm{m} / \mathrm{z})\left[\mathrm{C}_{31} \mathrm{H}_{33} \mathrm{~N}_{3} \mathrm{O}_{13} \mathrm{Na}\right]^{+}:$678.1913. Cald. for $\left[\mathrm{C}_{31} \mathrm{H}_{33} \mathrm{~N}_{3} \mathrm{O}_{13} \mathrm{Na}\right]^{+}: 678.1911$.

$(2 R, 3 R, 4 S, 5 S, 6 S)-2$-(Acetoxymethyl)-6-((1-(2,2-dimethyl-4,5dioxo-2,3,4,5-tetrahydronaphtho[1,2- $b]$ furan-3-yl)-1H-1,2,3-triazol-4-yl)methoxy)tetrahydro- $2 \mathrm{H}$-pyran-3,4,5-triyl triacetate (35). Using $(2 R, 3 R, 4 S, 5 S, 6 S)$-2-(acetoxymethyl)-6-(prop-2-yn-1yloxy)tetrahydro- $2 H$-pyran-3,4,5-triyl triacetate (424 mg, 1.1 $\mathrm{mmol}$ ), 35 was obtained as a yellow solid (556 mg, $0.85 \mathrm{mmol}$, $85 \%$ yield); mp $104-107{ }^{\circ} \mathrm{C} .{ }^{1} \mathrm{H}$ NMR $\left(400 \mathrm{MHz}, \mathrm{CDCl}_{3}\right) \delta: 8.20$ / $8.18(\mathrm{~m}, 1 \mathrm{H}), 7.84-7.72(\mathrm{~m}, 3 \mathrm{H}), 7.52 / 7.49(\mathrm{~s}, 1 \mathrm{H}), 5.98 / 5.95(\mathrm{~s}$, $1 \mathrm{H}), 5.39 / 5.38(\mathrm{~s}, 1 \mathrm{H}), 5.22-5.12(\mathrm{~m}, 1 \mathrm{H}), 5.03-4.92(\mathrm{~m}, 2 \mathrm{H})$, 
4.84-4.77 (m, 1H), 4.65-4.62 (m, 1H), 4.15-4.12 (m, 2H), 3.98$3.93(\mathrm{~m}, 1 \mathrm{H}), 2.13,2.11,2.04,2.03,1.97,1.96,1.77$ (seven singlets observed, $12 \mathrm{H}), 1.20 / 1.19(\mathrm{~s}, 3 \mathrm{H}), 0.90-0.83(\mathrm{~m}, 3 \mathrm{H}) .{ }^{13} \mathrm{C}$ NMR $\left(100 \mathrm{MHz}, \mathrm{CDCl}_{3}\right) \delta: 180.0,180.0,174.5,174.5,171.2$, $170.4,170.2,170.0,170.0,169.8,169.8,169.6,169.6,144.5$, $144.2,134.8,133.4,131.5,130.0,126.6,125.5$, 125.5, 122.5, 122.1, 111.3, 111.1, 100.7, 100.3, 96.0, 95.9, 70.9, 70.8, 70.7, 68.8, 68.7, 67.1, 67.0, 66.9, 66.8, 63.2, 62.7, 61.3, 61.3, 31.6, 29.0, 27.7, 22.6, 22.6, 21.2, 21.1, 20.7, 20.6, 20.5, 14.1, 11.4. ESI-MS: $(\mathrm{m} / \mathrm{z})$ $\left[\mathrm{C}_{31} \mathrm{H}_{33} \mathrm{~N}_{3} \mathrm{O}_{13} \mathrm{Na}\right]^{+}$: 678.1938. Cald. for $\left[\mathrm{C}_{31} \mathrm{H}_{33} \mathrm{~N}_{3} \mathrm{O}_{13} \mathrm{Na}\right]^{+}$: 678.1911.

\section{Acknowledgements}

This research was funded by grants from the Conselho Nacional de Desenvolvimento Científico e Tecnológico (CNPq 480719/ 2012-8, PVE 401193/2014-4, PQ-SR CNPq 302613/2013-7), FAPEMIG (Edital 01/2014), CAPES, FAPERJ, FAPEAL, CAPES/ PROCAD and PAPES/Fiocruz.

\section{Notes and references}

1 (a) WHO, Chagas disease in Latin America: an epidemiological update based on 2010 estimates, Wkly. Epidemiol. Rec., 2015, 90, 33; (b) A. Rassi Júnior, A. Rassi and J. M. de Rezende, Infect. Dis. Clin., 2012, 26, 275.

2 M. Steindel, L. K. Pacheco, D. Scholl, M. Soares, M. H. de Moraes, I. Eger, C. Kosmann, T. C. M. Sincero, P. H. Stoco, S. M. F. Murta, C. J. Carvalho-Pinto and E. C. Grisard, Diagn. Microbiol. Infect. Dis., 2008, 60, 25.

3 J. C. P. Dias, V. A. Neto and E. J. A. Luna, Rev. Soc. Bras. Med. Trop., 2011, 44, 375.

4 J. R. Coura and J. C. P. Dias, Mem. Inst. Oswaldo Cruz, 2009, $104,31$.

5 J. Gascon, C. Bern and M. J. Pinazo, Acta Trop., 2010, 115, 22. 6 G. A. Schmunis and Z. E. Yadon, Acta Trop., 2010, 115, 14.

7 A. Rassi Júnior, A. Rassi and J. A. Marin-Neto, Lancet, 2010, 375, 1388.

8 W. de Souza, Curr. Pharm. Des., 2002, 8, 269.

9 M. N. Soeiro and S. L. de Castro, Open Med. Chem. J., 2011, 5, 21.

10 (a) K. W. Wellington, RSC Adv., 2015, 5, 20309; (b) J. A. Urbina, J. Eukaryotic Microbiol., 2015, 62, 149.

11 G. Powis, Pharmacol. Ther., 1987, 35, 57.

12 E. A. Hillard, F. C. Abreu, D. C. M. Ferreira, G. Jaouen, M. O. F. Goulart and C. Amatore, Chem. Commun., 2008, 2612.

13 B. Hazra, M. Das Sarma and U. Sanyal, J. Chromatogr. B: Anal. Technol. Biomed. Life Sci., 2004, 812, 259.

14 C. C. Nawrat and C. J. Moody, Angew. Chem., Int. Ed., 2014, 53, 2056.

15 (a) E. N. da Silva Júnior, G. A. M. Jardim, R. F. S. MennaBarreto and S. L. de Castro, J. Braz. Chem. Soc., 2014, 25, 1780; (b) A. Cavalli and M. L. Bolognesi, J. Med. Chem., 2009, 52, 7339; (c) K. Vázquez, C. Espinosa-Bustos, J. SotoDelgado, R. A. Tapia, J. Varela, E. Birriel, R. Segura,
J. Pizarro, H. Cerecetto, M. González, M. Paulino and C. O. Salas, RSC Adv., 2015, 5, 65153.

16 R. Kharb, P. C. Sharma and M. S. Yar, J. Enzyme Inhib. Med. Chem., 2011, 26, 1.

17 S. Scodavolpe, S. Quaranta, B. Lacarelle and C. Solas, Ann. Biol. Clin., 2014, 72, 391.

18 R. Huisgen, G. Szeimies and L. Möbius, Chem. Ber., 1967, 100, 2494.

19 (a) H. C. Kolb and K. B. Sharpless, Drug Discovery Today, 2003, 8, 1128; (b) H. C. Kolb, M. G. Finn and K. B. Sharpless, Angew. Chem., Int. Ed., 2001, 40, 2004; (c) C. W. Tornøe, C. Christensen and M. Meldal, J. Org. Chem., 2002, 67, 3057; (d) V. V. Rostovtsev, L. G. Green, V. V. Fokin and K. B. Sharpless, Angew. Chem., Int. Ed., 2002, 41, 2596; (e) M. Meldal and C. W. Tornøe, Chem. Rev., 2008, 108, 2952.

20 (a) S. G. Agalave, S. R. Maujan and V. S. Pore, Chem.-Asian J., 2011, 6, 2696; (b) J. Hou, X. Liu, J. Shen, G. Zhao and P. G. Wang, Expert Opin. Drug Discovery, 2012, 7, 489; (c) D. Pasini, Molecules, 2013, 18, 9512.

21 S. L. de Castro, F. S. Emery and E. N. da Silva Júnior, Eur. J. Med. Chem., 2013, 69, 678.

22 A. V. Pinto and S. L. de Castro, Molecules, 2009, 14, 4570.

23 (a) K. C. G. Moura, K. Salomão, R. F. S. Menna-Barreto, F. S. Emery, M. C. F. R. Pinto, A. V. Pinto and S. L. de Castro, Eur. J. Med. Chem., 2004, 39, 639; (b) K. C. G. Moura, F. S. Emery, C. N. Pinto, M. C. F. R. Pinto, A. P. Dantas, K. Salomão, S. L. de Castro and A. V. Pinto, J. Braz. Chem. Soc., 2001, 12, 325; (c) A. V. Pinto, C. NevesPinto, M. C. F. R. Pinto, R. M. Santa Rita, C. Pezzella and S. L. de Castro, Arzneim.-Forsch., 1997, 47, 74; (d) C. NevesPinto, A. P. Dantas, K. C. G. Moura, F. S. Emery, P. F. Polequevitch, M. C. F. R. Pinto, S. L. de Castro and A. V. Pinto, Arzneim.-Forsch., 2000, 50, 1120.

24 (a) R. F. S. Menna-Barreto, J. R. Corrêa, C. M. Cascabulho, M. C. Fernandes, A. V. Pinto, M. J. Soares and S. L. de Castro, Parasitology, 2009, 136, 499; (b) R. F. S. MennaBarreto, J. R. Corrêa, A. V. Pinto, M. J. Soares and S. L. de Castro, Parasitol. Res., 2007, 101, 895; (c) R. F. S. MennaBarreto, A. Henriques-Pons, A. V. Pinto, J. A. MorgadoDiaz, M. J. Soares and S. L. de Castro, J. Antimicrob. Chemother., 2005, 56, 1034.

25 E. N. da Silva Júnior, M. C. B. V. de Souza, M. C. Fernandes, R. F. S. Menna-Barreto, M. C. F. R. Pinto, F. A. Lopes, C. A. de Simone, C. K. Z. Andrade, A. V. Pinto, V. F. Ferreira and S. L. de Castro, Bioorg. Med. Chem., 2008, 16, 5030.

26 E. N. da Silva Júnior, R. F. S. Menna-Barreto, M. C. F. R. Pinto, R. S. F. Silva, D. V. Teixeira, M. C. B. V. de Souza, C. A. de Simone, S. L. de Castro, V. F. Ferreira and A. V. Pinto, Eur. J. Med. Chem., 2008, 42, 1774 .

27 E. N. da Silva Júnior, I. M. M. de Melo, E. B. T. Diogo, V. A. Costa, J. D. de Souza Filho, W. O. Valença, C. A. Camara, R. N. de Oliveira, A. S. de Araújo, F. S. Emery, M. R. dos Santos, C. A. de Simone, R. F. S. Menna-Barreto and S. L. de Castro, Eur. J. Med. Chem., 2012, 52, 304. 
28 R. S. F. Silva, E. M. Costa, U. L. T. Trindade, D. V. Teixeira, M. C. F. R. Pinto, G. L. Santos, V. R. S. Malta, C. A. de Simone, A. V. Pinto and S. L. de Castro, Eur. J. Med. Chem., 2006, 41, 526.

29 R. F. S. Menna-Barreto, R. L. S. Gonçalves, E. M. Costa, R. S. F. Silva, A. V. Pinto, M. F. Oliveira and S. L. de Castro, Free Radical Biol. Med., 2009, 47, 644.

30 A. Dondoni, Chem.-Asian J., 2007, 2, 700.

31 I. Carvalho, P. Andrade, V. L. Campo, P. M. Guedes, R. SestiCosta, J. S. Silva, S. Schenkman, S. Dedola, L. Hill, M. Rejzek, S. A. Nepogodiev and R. A. Field, Bioorg. Med. Chem., 2010, 18, 2412.

32 V. L. Campo, R. Sesti-Costa, Z. A. Carneiro, J. S. Silva, S. Schenkman and I. Carvalho, Bioorg. Med. Chem., 2012, 20, 145 .

33 P. Singh, A. Anand and V. Kumar, Eur. J. Med. Chem., 2014, 85, 758.

34 (a) Z. Nowakowska, Eur. J. Med. Chem., 2007, 42, 125; (b) D. I. Batovska and I. T. Todorova, Curr. Clin. Pharmacol., 2010, 5, 1; (c) E. H. Zhang, R. F. Wang, S. Z. Guo and B. Liu, J. Evidence-Based Complementary Altern. Med., 2013, 2013, 815621; (d) M. J. Matos, S. Vazquez-Rodriguez, E. Uriarte and L. Santana, Expert Opin. Ther. Pat., 2015, 25, 351.

35 M. Roussaki, B. Hall, S. C. Lima, A. C. da Silva, S. Wilkinson and A. Detsi, Bioorg. Med. Chem. Lett., 2013, 23, 6436.

36 J. Ryczak, M. Papini, A. Lader, A. Nasereddin, D. Kopelyanskiy, L. Preu, C. L. Jaffe and C. Kunick, Eur. J. Med. Chem., 2013, 64, 396.

37 Z. Qiao, Q. Wang, F. Zhang, Z. Wang, T. Bowling, B. Nare, R. T. Jacobs, J. Zhang, D. Ding, Y. Liu and H. Zhou, J. Med. Chem., 2012, 55, 3553.

38 C. Ibis, A. F. Tuyun, H. Bahar, S. S. Ayla, M. V. Stasevych, R. Y. Musyanovych, O. Komarovska-Porokhnyavets and V. Novikov, Med. Chem. Res., 2013, 22, 2879.

39 V. Jamier, L. A. Ba and C. Jacob, Chem.-Eur. J., 2010, 16, 10920.

40 (a) S. Shaaban, R. Diestel, B. Hinkelmann, Y. Muthukumar, R. P. Verma, F. Sasse and C. Jacob, Eur. J. Med. Chem., 2012, 58, 192; (b) F. H. Fry, A. L. Holme, N. M. Giles, G. I. Giles, C. Collins, K. Holt, S. Pariagh, T. Gelbrich, M. B. Hursthouse, N. J. Gutowskic and C. Jacob, Org. Biomol. Chem., 2005, 3, 2579; (c) M. Doering, B. Diesel, M. C. H. Gruhlke, U. M. Viswanathan, D. Manikov, M. Chovanec, T. Burkholz, A. J. Slusarenko, A. K. Kiemer and C. Jacob, Tetrahedron, 2012, 68, 10577.

41 A. V. Pinto, M. C. F. R. Pinto and C. G. T. de Oliveira, An. Acad. Bras. Cienc., 1982, 54, 108.

42 E. H. G. Cruz, C. M. B. Hussene, G. G. Dias, E. B. T. Diogo, I. M. M. de Melo, B. L. Rodrigues, M. G. da Silva, W. O. Valença, C. A. Camara, R. N. de Oliveira, Y. G. de Paiva, M. O. F. Goulart, B. C. Cavalcanti, C. Pessoa and E. N. da Silva Júnior, Bioorg. Med. Chem., 2014, 22, 1608.

43 (a) R. T. Blickenstaff, W. R. Hanson, S. Reddy and R. Witt, Bioorg. Med. Chem., 1995, 3, 917; (b) V. Tomar, G. Bhattacharjee, Kamaluddin, S. Rajakumar, K. Srivastava and S. K. Puri, Eur. J. Med. Chem., 2010, 45, 745; (c)
F. L. Ansari, S. Umbreen, L. Hussain, T. Makhmoor, S. A. Nawaz, M. A. Lodhi, S. N. Khan, F. Shaheen, M. I. Choudhary and Atta-ur-Rahman, Chem. Biodiversity, 2005, 2, 487.

44 L. F. Fieser and M. Fieser, J. Am. Chem. Soc., 1948, 70, 3215. 45 G. A. M. Jardim, T. T. Guimarães, M. C. F. R. Pinto,

B. C. Cavalcanti, K. M. de Farias, C. Pessoa, C. C. Gatto,

D. K. Nair, I. N. N. Namboothiri and E. N. da Silva Júnior, Med. Chem. Commun., 2015, 6, 120.

46 A. J. M. da Silva, C. D. Buarque, F. V. Brito, L. Aurelian, L. F. Macedo, L. H. Malkas, R. J. Hickey, D. V. S. Lopes, F. Noël, Y. L. B. Murakami, N. M. V. Silva, P. A. Melo, R. R. B. Caruso, N. G. Castro and P. R. R. Costa, Bioorg. Med. Chem., 2002, 10, 2731.

47 (a) G. A. M. Jardim, E. H. G. da Cruz, W. O. Valença, J. M. Resende, B. L. Rodrigues, D. F. Ramos, R. N. de Oliveira, P. E. A. Silva and E. N. da Silva Júnior, J. Braz. Chem. Soc., 2015, 26, 1013; (b) I. C. Chipoline, V. F. Ferreira and F. C. da Silva, Curr. Org. Synth., 2015, 12, 565.

48 Z. Wang, M. Matin and S. Sheikh, Molecules, 2005, 10, 1325. 49 K. P. R. Kartha and R. A. Field, Tetrahedron, 1997, 53, 11753. 50 R. Yang, H. Ding, Y. Song, W. Xiao, Q. Xiao and J. Wu, Lett. Org. Chem., 2008, 5, 518.

51 A. A. Vieira, I. R. Brandão, W. O. Valença, C. A. de Simone, B. C. Cavalcanti, C. Pessoa, T. R. Carneiro, A. L. Braga and E. N. da Silva Júnior, Eur. J. Med. Chem., 2015, 101, 254.

52 E. N. da Silva Júnior, T. T. Guimarães, R. F. S. MennaBarreto, M. C. F. R. Pinto, C. A. de Simone, C. Pessoa, B. C. Cavalcanti, J. R. Sabino, C. K. Z. Andrade, M. O. F. Goulart, S. L. de Castro and A. V. Pinto, Bioorg. Med. Chem., 2010, 18, 3224.

53 M. C. Fernandes, E. N. da Silva Júnior, A. V. Pinto, S. L. de Castro and R. F. S. Menna-Barreto, Parasitology, 2012, 139, 26.

54 Y. G. de Paiva, F. R. Ferreira, T. L. Silva, E. Labbé, O. Buriez, C. Amatore and M. O. F. Goulart, Curr. Top. Med. Chem., 2015, 15, 136.

55 (a) M. O. F. Goulart, C. L. Zani, J. Tonholo, L. R. Freitas, F. C. de Abreu, A. B. Oliveira, D. S. Raslan, S. Starling and E. Chiari, Bioorg. Med. Chem. Lett., 1997, 7, 2043; (b) E. N. da Silva Júnior, M. A. B. F. de Moura, A. V. Pinto, M. C. F. R. Pinto, M. C. B. V. Souza, A. J. Araújo, C. Pessoa, L. V. Costa-Lotufo, R. Montenegro, M. O. de Moraes, M. O. F. Goulart and V. F. Ferreira, J. Braz. Chem. Soc., 2009, 20, 635.

56 E. B. T. Diogo, G. G. Dias, B. L. Rodrigues, T. T. Guimarães, W. O. Valença, C. A. Camara, R. N. de Oliveira, M. G. da Silva, V. F. Ferreira, Y. G. de Paiva, M. O. F. Goulart, R. F. S. MennaBarreto, S. L. de Castro and E. N. da Silva Júnior, Bioorg. Med. Chem., 2013, 21, 6337.

57 G. I. Giles, K. M. Tasker, R. J. K. Johnson, C. Jacob, C. Peers and K. N. Green, Chem. Commun., 2001, 2490.

58 H. Viertler, J. Gruber and V. L. Pardini, Anodic oxidation of sulfur- and selenium-containing compounds, in Organic Electrochemistry, ed. H. Lund and O. Hammerich, Marcel 
Dekker, Inc., New York, 4th edn, 2001, ch. 17, H. Lund and M. M. Baizer, pp. 621-668 and included references.

59 R. R. France, N. V. Rees, J. D. Wadhawan, A. J. Fairbanks and R. G. Compton, Org. Biomol. Chem., 2004, 2, 2188.

60 F. R. Ferreira, S. B. Ferreira, A. J. Araújo, J. D. B. M. Filho, C. Pessoa, M. O. Moraes, L. V. Costa-Lotufo, R. C. Montenegro, F. C. da Silva, V. F. Ferreira, J. G. da
Costa, F. C. de Abreu and M. O. F. Goulart, Electrochim. Acta, 2013, 110, 634.

61 B. Dakova, L. Lambews and M. Evers, Electrochim. Acta, 1994, 39, 2363.

62 M. O. F. Goulart, F. C. Abreu and A. M. O. Brett, Electroanalysis, 2002, 14, 29.

63 S. L. de Castro and M. N. L. Meirelles, Mem. Inst. Oswaldo Cruz, 1990, 85, 95. 